January 2009

\title{
International Transfer Pricing for Goods and Intangible Asset Licenses in a Decentralized Multinational Corporation: Review and Extensions
}

Peter C. Dawson

Stephen M. Miller

University of Connecticut and University of Nevada, Las Vegas

Follow this and additional works at: https://opencommons.uconn.edu/econ_wpapers

\section{Recommended Citation}

Dawson, Peter C. and Miller, Stephen M., "International Transfer Pricing for Goods and Intangible Asset Licenses in a Decentralized Multinational Corporation: Review and Extensions" (2009). Economics Working Papers. 200906.

https://opencommons.uconn.edu/econ_wpapers/200906 


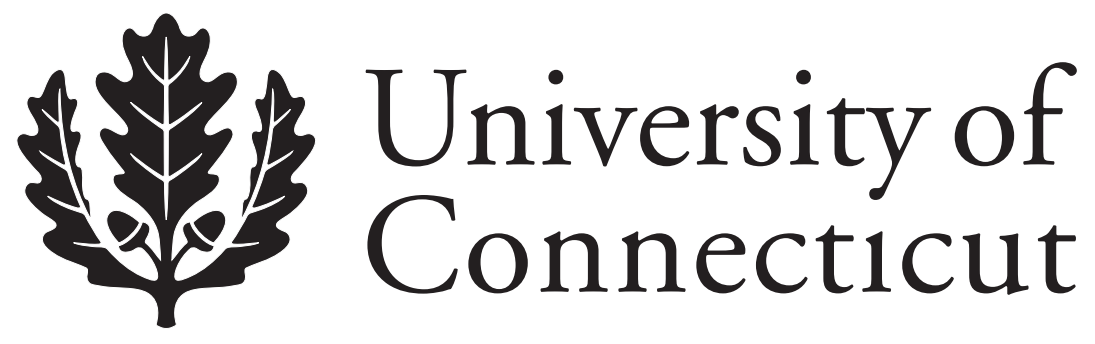

Department of Economics Working Paper Series

International Transfer Pricing for Goods and Intangible Asset Licenses in a Decentralized Multinational Corporation: Review and Extensions

Peter C. Dawson

Dallas, Texas

Stephen M. Miller

University of Connecticut and University of Nevada, Las Vegas

Working Paper 2009-06

January 2009

341 Mansfield Road, Unit 1063

Storrs, CT 06269-1063

Phone: (860) 486-3022

Fax: (860) 486-4463

http://www.econ.uconn.edu/

This working paper is indexed on RePEc, http://repec.org/ 


\begin{abstract}
We review and extend the core literature on international transfer price manipulation to avoid or evade taxes. Under negotiated transfer pricing with a viable bargaining structure, including performance evaluation disconnected from the transfer price, divisions voluntarily exchange accurate information to obtain firm-wide optimality, a result not dependent on restraint from exercising internal market power. For intangible licenses, a larger optimal profit shift for a given tax rate change strengthens incentives for transfer pricing abuse. In practice, an intangible's arm's length range is viewed as a guideline, a context where incentives for abuse materialize. Transfer pricing for intangibles obliges greater tax authority scrutiny.
\end{abstract}

Journal of Economic Literature Classification: F23, H25, H26, L29, O34

Keywords: Negociated transfer pricing, licensing intangibles, decentralized MNC 


\section{Introduction}

Guttman (1999) argues that more than 60 percent of international trade occurs through intra-firm trade between related or controlled divisions of multinational corporations (MNCs). Stanley (2001) refers to this figure as a "long-standing statistic." Using U.S. trade data reported by the U.S. Bureau of Economic Analysis for 1981 to 2000, Diewert, Alterman, and Eden (2005) report that intra-firm trade equals 31 to 40 percent of the value of aggregate annual U.S. exports and 37 to 44 percent of the value of aggregate annual U.S. imports (p. 4), and estimate that intra-firm trade equals 30 to 40 percent of world trade (p. 40). If accurate, then approximately 30 to 60 percent of the dollar value of international trade occurs at prices, called "transfer prices", that MNCs determine internally rather than at arm's length in an external market. In sum, intra-firm trade and transfer pricing constitute a large portion of international trade.

The extent of internal MNC trade creates a substantial opportunity for MNCs to adjust transfer prices to shift profit earned in high-tax countries to related corporate entities or divisions in low-tax or tax-haven countries. This opportunity, coupled with an MNC's fiduciary imperative to maximize world-wide after-tax profit, raises governmental concerns about abusive transfer pricing practices and their potential adverse effect on tax collections in high-tax jurisdictions. In response, many countries revised existing transfer pricing regulations or introduced new ones. To improve the effectiveness of existing regulations, many countries introduced documentation and penalty rules. Given the global web of transfer pricing regulations and the "increased compliance burden and enforcement" associated with them, Ernst and Young (2007) project that transfer pricing will constitute the "most important," or at least a "very important," tax issue for 74 percent of MNC tax departments in the next two years (pp. 9-11).

But, in practice, does the typical MNC significantly adjust its transfer price(s) to avoid or 
evade corporate income taxes? In an unpublished federally-funded study of U.S. Customs data, Pak and Zdanowicz (2002) ${ }^{1}$ report dramatic over-invoicing of U.S. imports and under-invoicing of U.S. exports, creating an estimated aggregate $\$ 53.1$ billion loss in U.S. federal tax revenue in 2001 (Diewert, Alterman, and Eden 2005, p. 4; Dorgman 2002). In contrast, Eden (2003) concludes "empirical evidence for transfer pricing manipulation exists but is not overwhelming and that most evidence has been by inference from income-shifting studies" (p. 7). ${ }^{2}$ Diewert, Alterman, and Eden (2004) conclude that the empirical literature on the extent of transfer pricing manipulation proves "mixed" (p. 3) and indicate that, in practice, transfer price manipulation does not occur to the degree suggested in Pak and Zdanowicz (2002), or to the degree inferred from traditional transfer pricing theory (p. 3). Nonetheless, given the importance of transfer pricing on an MNC's global tax liability and after-tax profit, and on host governments' tax collections, this paper revisits the question of how the typical MNC adjusts its transfer price(s) when relative national corporate profit tax rates change, ceteris paribus.

Horst (1971) analyzes transfer pricing in a traditional neoclassical firm, assuming a centralized decision-making (CDM) structure within the MNC. Horst concludes that MNCs shift profit earned in high-tax jurisdictions to low-tax jurisdictions. His model without an import tariff implies that MNCs experience the economic incentive to shift all before-tax profit, when unconstrained, to their controlled divisions in low-tax jurisdictions (i.e., a complete profit shift). Such a dramatic analytical result implies that governments should thoroughly monitor transfer pricing practices to prevent abuses. The CDM structure implicit in the traditional neoclassical firm, an empty "black box," however, does not adequately capture the management structure that

\footnotetext{
${ }^{1}$ See also Pak and Zdanowicz (1994a, 1994b).

${ }^{2}$ Empirical studies that consider how transfer pricing shifts profit include Lall (1973), Vaitsos (1974), Jenkins and Wright (1975), Kopits (1976), Lecraw (1985), Bernard and Weiner (1989, 1990), Dworin (1990), Grubert and Mutti (1991), Harris et al. (1993), and Hines and Rice (1994).
} 
exists within the typical MNC. That is, the neoclassical firm does not consider the different decision-makers and agency relationships within the typical modern firm. Since MNCs operate in geographically dispersed locations and, in general, choose a greater degree of decentralized decision-making (DDM, Bartlett and Ghoshal, 1993), we assume DDM.

In sum, this paper considers how the typical MNC sets its transfer prices in response to changes in relative tax rates under DDM. Section 2 presents a synthesis model of transfer pricing to facilitate a comparison of the assumptions, conclusions, and implications of the core economic literature. Section 3 compares the core centralized and decentralized economic models of transfer pricing that Horst (1971), Hirshleifer (1956, 1964), and Bond (1980) develop. CDM and DDM prove fundamental to understand differences in these alternative approaches. Section 4 extends the DDM model of Bond (1980), where top management selects the transfer price (i.e., centralized transfer pricing) and division managements select intra-firm trade and division output. Section 5 departs further from the core CDM model, where division management now selects the transfer price, through negotiation (i.e., negotiated transfer pricing), as well as the quantity of intra-firm trade and division output. This model includes strategic interactions between each division's management in the transfer price negotiation process. Section 6 extends the decentralized transfer pricing model to analyze intra-firm licensing of intangible assets. Section 7 concludes by placing our findings in a broader perspective.

\section{A Synthesis Model for Transfer Pricing}

Our basic model provides a general framework to examine and synthesize the core economic literature on transfer pricing from both the CDM and DDM strands, as well as to develop the extensions in Sections 4, 5, and 6. Eden (1985) assumes CDM to review and compare several CDM papers, including Horst (1971) and Copithorne (1971). With our synthesis model, we 
compare two seemingly disconnected economic models of transfer pricing -- the traditional CDM model, as in Horst (1971), and the DDM models of Hirshleifer (1956, 1964), Bond (1980), and our extended analyses.

The synthesis model assumes, for simplicity, that the MNC owns two divisions, one operating in the domestic country (country 1) and the other operating in a foreign country (country 2), as in Hirshleifer (1956, 1964), Horst (1971), and Bond (1980). The parent company operates in country 1 along with the central office, where top management resides, and an operating division (division 1), where division 1's management resides. Division 2's operations constitute a wholly-owned and controlled subsidiary of the parent company, incorporated under the laws of country 2. By convention, intra-firm trade flows from division 1 to division 2, which may reflect an MNC's vertical or horizontal integration strategy. Top management maximizes the MNC's global after-tax profit, subject to regulatory constraints in both countries. We define the MNC's domestic currency-denominated global after-tax profit as follows:

$$
\Pi_{M N C}^{d c}=\left(1-t_{1}\right) \Pi_{1}^{d c}+(1 / E)\left(1-t_{2}\right) \Pi_{2}^{f c}
$$

where $\Pi_{1}^{d c}$ is the domestic currency value of division 1's before-tax profit, $\Pi_{2}^{f c}$ is the foreign currency value of division 2's before-tax profit, $t_{1}$ and $t_{2}$ are country 1 's and 2's effective corporate income tax rates, and $E$ is the nominal exchange rate defined as foreign currency per domestic currency. Furthermore,

$$
\begin{aligned}
& \Pi_{1}^{d c}=P_{1}^{d c} X_{11}+P_{12}^{d c} X_{12}-C_{1}^{d c}\left(X_{1}\right), \text { and } \\
& \Pi_{2}^{f c}=P_{2}^{f c} Y_{2}-\gamma_{2}^{f c}\left(Y_{2}\right)-P_{12}^{f c} X_{12},
\end{aligned}
$$

where division 1 produces good $1, X_{1}$, sold in country $1, X_{11}$, and also sold intra-firm to division 2 in country $2, X_{12}$, at a per-unit domestic currency transfer price of $P_{12}^{d c}$, and 
$X_{1}=X_{11}+X_{12}$. Division 1 incurs a domestic currency cost of producing good $1, C_{1}^{d c}$. Division 2 uses $X_{12}$ as an input in the production of good 2, $Y_{2}$, for sale in country 2. Division 2 incurs a foreign currency production cost, $\gamma_{2}^{f c} \cdot{ }^{3}$ Division 2 uses $X_{12}$ as a variable resource input in its production of good 2, apart from the variable labor/input costs already included in $\gamma_{2}^{f c} . P_{12}^{f c} X_{12}$ equals division 2's intra-firm foreign-currency input cost. Since the parent company operates in country 1, the MNC must repatriate division 2's foreign-currency-denominated before-tax profit, $\Pi_{2}^{f c}$, in domestic currency (i.e., $\Pi_{2}^{d c}=\Pi_{2}^{f c} / E$ ), where it enters the MNC's consolidated financial statements. That is, division 2's before-tax profit, $\Pi_{2}^{f c}$, enters top management's profitmaximizing objective function as $\Pi_{2}^{d c}$.

By convention, division 2 possesses a unit fixed-coefficient production function. In other words, one unit of $X_{12}$ can produce one unit of $Y_{2}$ (i.e., $\left.Y_{2}=f\left(X_{12}\right)=X_{12}\right)$. Bond (1980) argues that relaxing this assumption does not alter the quality of the results (p. 196). In addition, no outside market for the intermediate good exists, so $X_{11}=0$ and $X_{1}=X_{12}$. Also, division 2 faces a perfectly competitive output market (i.e., $P_{2}^{f c}=\overline{P_{2}^{f c}}$ ). Therefore, we can write the synthesis model in domestic currency as follows:

$$
\begin{aligned}
& \Pi_{M N C}=\left(1-t_{1}\right) \Pi_{1}+\left(1-t_{2}\right) \Pi_{2}, \\
& \Pi_{1}=P_{12} X_{12}-C_{1}\left(X_{12}\right), \text { and } \\
& \Pi_{2}=\Pi_{2}^{f c} / E=\overline{P_{2}} X_{12}-\gamma_{2}\left(X_{12}\right)-P_{12} X_{12} .
\end{aligned}
$$

\footnotetext{
${ }^{3}$ If division 2 resells good 1 in country 2 as good 2, division 2's output is $X_{2}$. In that case, $\gamma_{2}^{f c}$ equals division 2's cost of processing good 1 for resale as good 2. That is, re-packaging, re-labeling, and/or modifying the product to meet country 2's regulations or consumer tastes.
} 
In general, the intra-firm quantity traded depends on the transfer price (i.e., $X_{12}=X_{12}\left(P_{12}\right)$ ). This specification allows division managements, under DDM, to choose their respective quantities supplied and demanded. Under CDM, top management determines the quantity of intra-firm trade, which, from division managements' perspective, means $X_{12}=\overline{X_{12}}$ when they make their respective profit-maximizing decisions.

\section{The Core Literature}

\section{Centralized Decision-Making}

Horst (1971) considers the MNC under CDM. We modify our synthesis model to incorporate his assumptions. The MNC faces an import tariff or duty, $d_{2}$, in country 2 on the quantity of intrafirm trade. The MNC is horizontally integrated (i.e., division 2 resells $X_{12}$ as good 2, which is now $X_{2}$ instead of $Y_{2}$ ). Division 2 produces part of $X_{2}$ itself (i.e., $X_{22}$ ) with a production cost, $C_{22}$. Division 2 does not incur a processing cost for the portion of good 2 that it imports from division 1 , so $\gamma_{2}=0$. Finally, division 2 sells good 2 in an imperfectly competitive output market. Therefore, Horst's division 2 before-tax profit, in the notation of the synthesis model, is as follows:

$$
\Pi_{2}=P_{2} X_{2}-C_{22}\left(X_{22}\right)-\left(1+d_{2}\right) P_{12} X_{12},
$$

where $P_{2}=P_{2}\left(X_{2}\right), X_{2}=X_{22}+X_{12}, C_{22}$ is division 2's on-site cost of producing its portion of good 2, and $\left(1+d_{2}\right) P_{12} X_{12}$ is division 2's import cost including the tariff. An imperfectly competitive external market for the intra-firm good exists, where division 1 sells the intra-firm good to unrelated parties in country 1 as good $1, X_{11}$. Therefore, Horst's division 1 before-tax profit, in the notation of the synthesis model, becomes as follows: 


$$
\Pi_{1}=P_{1} X_{11}+P_{12} X_{12}-C_{1}\left(X_{1}\right)
$$

where $P_{1}=P_{l}\left(X_{11}\right)$. Equations (1'), (4), and (5) represent Horst's (1971) original CDM model.

Since the quantity of intra-firm trade, $X_{12}$, in Horst's (1971) model does not depend on the transfer price, $P_{12}$, he assumes CDM. Presumably, a centralized decision-maker (or decisionmaking unit) exists within the MNC that chooses the quantity of intra-firm trade. Several possible scenarios may underlie the CDM assumption: (i) The MNC operates as a traditional neoclassical firm, or "black box," with no explicit decision-makers or agency relationships, and the "firm" chooses the transfer price and the quantity of intra-firm trade to maximize $\Pi_{M N C}$; (ii) an owner-operated MNC faces no principal-agent problems, since the owner makes all operating divisions, and the owner chooses both the transfer price and quantity of intra-firm trade to maximize $\Pi_{M N C}$; or (iii) the MNC's top management implements a perfect management control system that corrects all principal-agent problems, such that division managements choose the transfer price and the quantity of intra-firm trade that maximize $\Pi_{M N C}$. Given the benefits of decentralization, $^{4}$ the typical MNC delegates decision-making authority to division managements in different countries. As such, an agency relationship between top management and division managements exists. Since a principal-agent (or agency) framework exists, for comparison purposes scenario (iii) will best characterize CDM.

\footnotetext{
${ }^{4}$ The benefits of DDM stem from increased productivity (Dean 1955, p. 65; Hass 1968, p. B-310; Sharav 1974, p. 56; Schaub 1978, p. 33), such as (1) division managers operate nearer to the relevant local information regarding their input and output prices (Ronen and McKinney 1970, p. 99), (2) division managers can more effectively coordinate the factors of production at the division level (Ronen and McKinney 1970, p. 99), (3) division managers face decreased information flows between top management and themselves, which reduces the bureaucratic inefficiencies inherent in a large centralized organization (Hass 1968, p. B-310), (4) division managers experience more motivation, which reduces "agency costs" (Hirshleifer 1964, p. 28; Grabski 1985, p. 34), and (5) division managers know better than top management their local markets (local customs, government policies and regulations, customer tastes and preferences, market trends, etc.) and, therefore, they know better how to produce the goods and services that satisfy the local market demand, laws, and regulations.
} 
Substitute equations (4) and (5) into equation (1') to obtain the following outcome:

$$
\Pi_{M N C}=Z+P_{12} X_{12}\left[\left(t_{2}-t_{1}\right)-\left(1-t_{2}\right) d_{2}\right],
$$

where $Z=\left(1-t_{1}\right)\left[P_{1} X_{11}-C_{1}\right]+\left(1-t_{2}\right)\left[P_{2} X_{2}-C_{22}\right]$. The first-order condition for an optimum yields the following:

$$
d \Pi_{M N C} / d P_{12}=X_{12}\left[\left(t_{2}-t_{1}\right)-\left(1-t_{2}\right) d_{2}\right] \geq 0 .
$$

Horst (1971) concludes that when $\left(t_{2}-t_{1}\right)$ exceeds (falls below) $\left(1-t_{2}\right) d_{2}, d \Pi_{M N C} / d P_{12}>0(<0)$ and the firm raises (lowers) the transfer price to the highest (lowest) allowable level. When the home (foreign) country imposes a high-enough tax rate (import tariff rate), the firm can "take a beating" on the import duty (home country corporate tax bill) to avoid a relatively high tax bill in country 1 (high import tariff in country 2).

The MNC abides by transfer pricing regulations. ${ }^{5}$ According to Eden (1985), Horst (1971) assumes that the arm's length price lies in the $P_{1}$ to $C_{1}^{\prime}$ range, since "he expected tax and tariff authorities to impose $M C_{1}$ as an effective lower bound and $P_{1}$ as an upper bound to $P_{12}$ " (p. 19). Booth and Jensen (1977) note that the transfer price is arbitrary and indeterminate when top management's profit-maximizing objective is unconstrained, such as by an arm's length constraint (p. 434). Schjelderup and Sørgard (1995) impose an internal profit constraint to ensure a determinate solution. Since an MNC cannot deduct losses earned in one country on its tax return in another country, the MNC does not adjust the transfer price such that it earns a loss in its high-tax division. Rather, the transfer price adjusts only until the high-tax division earns zero profit. Booth and Jensen (1977) show that the transfer price becomes determinate when top

\footnotetext{
${ }^{5}$ Under the U.S. transfer pricing regulations in $\$ 1.482$, a firm must report “arm’s length” income, which conforms to the "arm's length standard" $(\S 1.482-1(\mathrm{~b})(1))$.
} 
management constrains itself to meet minimum profit levels in each country.

We convert Horst's (1971) model into a DDM model similar to the models in Hirshleifer (1956, 1964) and Bond (1980), by adopting Bond's (1980) assumptions. First, each division faces a perfectly competitive output market. Second, no external market exists for the intra-firm good. Finally, the MNC is vertically integrated (i.e., division 2 does not produce the intra-firm good). Horst's original conclusion remains unchanged. In addition, we adopt Bond's (1980) assumption that $d_{2}=0$. Therefore, within the synthesis model, the modified Horst (1971) solution becomes

$$
d \Pi_{M N C} / d P_{12}=X_{12}\left[\left(t_{2}-t_{1}\right)\right] \geq 0 .
$$

When $t_{2}>t_{1}\left(t_{2}<t_{1}\right)$, the MNC chooses the highest (lowest) allowable transfer price to maximize $\Pi_{M N C}$, given its optimal choice of $\mathrm{X}_{12}$, where the arm's length range implicitly constrains the transfer price. ${ }^{6}$ The MNC raises (lowers) the transfer price to the upper (lower) arm's-length boundary of that range. That is, under CDM the transfer price maximizes $\Pi_{M N C}$ while obtaining equilibrium in the MNC's internal market (i.e., $X_{12}=X_{12}^{s}=X_{12}^{d}$ ).

\section{Decentralized Decision-Making}

Under DDM, the neoclassical firm can incorporate a principal-agent framework. That is, we now distinguish between top management and division-level managements, where top management delegates some decision-making authority over division operations to division managements. A management control system evaluates and rewards division managers based on division profit in an effort to minimize the agency costs associated with the delegation of authority. Albeit it in a

\footnotetext{
${ }^{6}$ The assumption of an arm's length range proves appropriate, given existing tax policy. For example, under the U.S. transfer pricing regulations, the arm's length transfer price must fall within the interquartile range of prices determined under the best transfer pricing method $(\S 1.482-1(\mathrm{e}))$.
} 
limited way, the neoclassical firm under DDM more realistically captures the internal workings of the modern MNC. ${ }^{7}$

Hirshleifer's $(1956,1964)$ model. The domestic divisionalized firm faces an identical corporate profit tax rate in each state or region in which it operates. Therefore, in equation $\left(1^{\prime}\right), t_{1}=t_{2}$. In Hirshleifer's decentralized firm, division managements choose the transfer price through negotiation (i.e., negotiated transfer pricing) and choose the quantity of intra-firm trade (and division output). Under DDM, division managements respond to changes in the negotiated transfer price by adjusting the quantity of the intra-firm good supplied and demanded. According to the divisions' profit maximization problems, an increase in the negotiated transfer price causes division 1 to increase the quantity of the intra-firm good it supplies (i.e., $d P_{12} / d X_{12}^{s *}=C_{1}^{\prime \prime}>0$ ) while simultaneously causing division 2 to decrease the quantity of the intra-firm good it demands (i.e., $\left.d P_{12} / d X_{12}^{d^{*}}=-\gamma_{2}^{\prime \prime}<0\right){ }^{8}$ We illustrate the internal market supply and demand curves in Figure 1.

In Hirshleifer $(1956,1964)$, top management wants autonomous divisions to negotiate the equilibrium transfer price, $P_{12}^{0}$ (superscript " 0 " refers to internal equilibrium). The efficient transfer price $P_{12}^{0}$ produces equilibrium in the internal market. Under Hirshleifer's assumption of equal tax rates, $P_{12}^{0}$ also equals the profit-maximizing transfer price. When $P_{12}^{0}$ is chosen, Hirshleifer (1956) calls this "marginal cost pricing for the intermediate product", since the transfer price equals division 1's marginal cost, $C_{l}^{\prime}$, which he clarifies by noting "the sum of the

\footnotetext{
${ }^{7}$ General Motors was, perhaps, the first multi-division firm to adopt a decentralized corporate structure in the 1920s, when it divided its corporate divisions into separate profit centers. As firms adopted decentralized corporate structures, scholars began to model the modern firm, including MNCs, as decentralized organizations.

${ }^{8}$ See Appendix A for these derivations.
} 
divisional marginal costs equal to price (in the perfectly competitive case) or marginal revenue (in the imperfectly competitive case) in the final market" (p. 175). ${ }^{9}$ That is, when the firm chooses the transfer price such that $C_{1}^{\prime}+\gamma_{2}^{\prime}=\overline{P_{2}}$ (i.e., the combination of conditions 1 and 2 below), it promotes both resource efficiency and firm-wide profit-maximizing. If autonomous divisions negotiate $P_{12}^{0}$, the following maximizing conditions (Hirshleifer 1964, p. 31) hold:

1. Division 1: $P_{12}=C_{1}^{\prime}$,

2. Division 2: $P_{12}=\overline{P_{2}}-\gamma_{2}^{\prime}$, and

3. Firm-wide: $X_{12}^{s}=X_{12}^{d}=X_{12}$.

No guarantee exists that autonomous divisions will choose a negotiated transfer price and intra-firm quantity of $P_{12}^{0}$ and $X_{12}^{0}$, however. Rational division managements may exploit their internal (monopolistic or monopsonistic) market power. To overcome potentially dysfunctional effects, Hirshleifer $(1956,1964)$ suggests a "neutral umpire" or "auctioneer" to facilitate the transfer price negotiations. Even though a neutral umpire aims to minimize the exercise of internal market power, rational divisions possess an incentive to misinform the neutral umpire. "[I]n the process of exchanging information, even through a neutral umpire, it may be in the interest of either party to give inaccurate replies in the hopes of achieving a more favorable price" (Hirshleifer 1964, p. 32). Under conditions of imperfect information, top management chooses a transfer pricing rule (e.g., a neutral umpire) intended to lead autonomous divisions to choose $P_{12}^{0}$. Divisions act within a firm's hierarchy, including policies designed to achieve corporate objectives. If successful, top management effectively chooses both the transfer price and quantity of intra-firm trade.

\footnotetext{
${ }^{9}$ Also, at $P_{12}^{0}$, division 2's marginal cost, $\gamma_{2}^{\prime}$, equals division 2's net marginal revenue, $\overline{P_{2}}-P_{12}$.
} 
Bond's (1980) model. The decentralized MNC faces potentially different tax rates. Bond (1980) characterizes decentralization by top management choosing the transfer price (i.e., centralized transfer pricing) and division managements choosing the quantity of intra-firm trade and division output. As in Hirshleifer $(1956,1964)$, divisions respond to changes in the transfer price by adjusting the quantity of the intra-firm good supplied and demanded. Bond's model contains equations $\left(1^{\prime}\right),\left(2^{\prime}\right)$, and $\left(3^{\prime}\right)$ of the synthesis model. Given the transfer price set by top management through centralized transfer pricing, each division chooses its optimal internal quantity of the intra-firm good. The divisions maximize as follows:

$$
\begin{aligned}
& \text { Division 1: }\left.\quad \operatorname{Max}_{X_{12}^{s}}\left(1-t_{1}\right) \Pi_{1}\right|_{P_{12}} \Rightarrow \quad\left(1-t_{1}\right)\left[P_{12}-C_{1}^{\prime}\right]=0 \text {; and } \\
& \text { Division 2: }\left.\quad \operatorname{Max}_{X_{12}^{d}}\left(1-t_{2}\right) \Pi_{2}\right|_{P_{12}} \Rightarrow \quad\left(1-t_{2}\right)\left[\overline{P_{2}}-\gamma_{2}^{\prime}-P_{12}\right]=0 .
\end{aligned}
$$

In Bond (1980), top management chooses the transfer price to maximize $\Pi_{M N C}$, given known division supply and demand curves. ${ }^{10}$ Formally, top management's maximization problem is $\left.\operatorname{Max}_{P_{12}} \Pi_{M N C}\right|_{\substack{x_{i 2}^{s},\left(P_{12}\right)>0 \\ X_{12}^{2}\left(P_{12}\right)<0}}$. Bond calculates top management's first-order condition and evaluates it at the equilibrium transfer price $P_{12}^{0}$ as follows:

$$
d \Pi_{M N C} /\left.d P_{12}\right|_{P_{12}=P_{12}^{0}}=X_{12}^{0}\left(t_{2}-t_{1}\right)
$$

Bond concludes that when $t_{2}>t_{1}\left(t_{2}<t_{1}\right)$, top management raises (lowers) the transfer price from $P_{12}^{0}$ to maximize $\Pi_{M N C}$. Equilibrium in the internal market occurs when top management

\footnotetext{
${ }^{10}$ In Hirshleifer $(1956,1964)$, this perfect information assumption would allow the neutral umpire to choose $P_{12}^{0}$ without an iterative process. In Bond (1980), top management knows the division supply and demand curves and chooses $P_{12}^{0}$ directly.
} 
sets the transfer price at $P_{12}^{0}$, which, in turn, occurs in the trivial case where $t_{1}=t_{2}$. Choosing $P_{12}^{0}$ does not maximize $\Pi_{M N C}$ when tax rates differ, however.

In the modified Horst (1971) model, different tax rates cause the centralized MNC to raise or lower the transfer price by the maximum amount allowed by tax law. How much does top management in Bond's (1980) decentralized MNC raise or lower the transfer price? Bond derives optimal markup and markdown conditions. The optimal markup rate equals

$$
\frac{P_{12}-C_{1}^{\prime}}{P_{12}}=\frac{\left(t_{2}-t_{1}\right)}{\eta\left(1-t_{1}\right)}
$$

and the optimal markdown rate equals

$$
\frac{\left(\overline{P_{2}}-\gamma_{2}^{\prime}\right)-P_{12}}{P_{12}}=\frac{\left(t_{2}-t_{1}\right)}{\varepsilon\left(1-t_{2}\right)},
$$

where $\eta=\left(\partial X_{12}^{d} / \partial P_{12}\right)\left(P_{12} / X_{12}^{d}\right)$ is division 2's transfer price elasticity of demand for $X_{12}$, and $\varepsilon=\left(\partial X_{12}^{s} / \partial P_{12}\right)\left(P_{12} / X_{12}^{s}\right)$ is division 1's transfer price elasticity of supply of $X_{12}$. Bond concludes that when $t_{2}>t_{1}\left(t_{2}<t_{1}\right)$, the optimal markup (markdown) depends on the relative magnitude of the tax differential and the transfer price elasticity of demand (supply).

Bond (1980) raises the possibility of a transfer price within, rather than on, the arm's length boundary. Under CDM, division management does not reduce the quantity of intra-firm trade when the transfer price changes, which frees top management to choose the highest or lowest allowable transfer price, a boundary solution. Under DDM, division management may lower the quantity of intra-firm trade below $X_{12}^{0}$ in response to a change in the transfer price. In that case, top management trades off a gain in $\Pi_{M N C}$ that comes from profit-shifting to minimize 
its global profit taxes with a loss in $\Pi_{M N C}$ that comes from a loss in internal efficiency. This tradeoff makes a solution within the arm's-length boundary possible. Top management, limited by the possible adverse effect of a fall in intra-firm trade on the MNC's global after-tax profit, probably adjusts the transfer price by less than the maximum allowed by tax law.

\section{Centralized Transfer Pricing: An Extension}

This section extends Bond (1980) by allowing the transfer price to take any value within the implicit arm's length constraint imposed by tax authorities. That is, the transfer price can differ from $P_{12}^{0}$ by finite amounts. Like Bond, we consider DDM with centralized transfer pricing, where top management chooses the transfer price subject to division 1's and division 2's given and known reaction functions. Division 1's (division 2's) reaction function equals its supply (demand) curve for the intra-firm good. Under DDM, each division's autonomous profitmaximizing behavior, a by-product of a decentralized corporate structure, is an internal constraint on top management's transfer price selection. Profit-maximizing division managements react to changes in the centrally-determined transfer price by adjusting their respective intra-firm quantities supplied and demanded. Division managements' reaction functions reflect their objective of maximizing division profits, an objective created by top management's use of a management control system that evaluates and rewards division management based on division profit. Under DDM, the quantity of intra-firm trade depends on the transfer price, where the direction of the quantity's response to changes in the transfer price depends on whether the MNC operates along division 1's supply curve or division 2's demand curve.

In addition to its internal constraint, top management maximizes the MNC's global aftertax profit subject to an external arm's length constraint that does not enter explicitly into the 
maximization problem. Given the significance of intra-firm trade, top management hires a competent consultant to determine the arm's length range (if not already known) and, therefore, can and does select a transfer price on, or within, the arm's length boundary. Top management's first-order condition for profit maximization implicitly defines the optimal transfer price. The total differential of the first-order condition generates the comparative static results as follows:

$$
\begin{aligned}
& \frac{\partial P_{12}^{*}}{\partial t_{1}}=\frac{\left(P_{12}-C_{1}^{\prime}\right) X_{12}^{\prime}+X_{12}}{C C} ; \text { and } \\
& \frac{\partial P_{12}^{*}}{\partial t_{2}}=\frac{\left(\overline{P_{2}}-\gamma_{2}^{\prime}-P_{12}\right) X_{12}^{\prime}-X_{12}}{C C},
\end{aligned}
$$

where $C C=\left(t_{1}-1\right)\left[\left(X_{12}^{\prime}\right)^{2} C_{1}^{\prime \prime}\right]+\left(t_{2}-1\right)\left[\left(X_{12}^{\prime}\right)^{2} \gamma_{2}^{\prime \prime}\right]+2 X_{12}^{\prime}\left(t_{2}-t_{1}\right)<0 .{ }^{11}$ To determine the sign of equations (14) and (15), we evaluate each result when the MNC operates along division 1's supply curve, along division 2's demand curve, and along both. Along the supply (demand) curve, division 1 's $\left(2\right.$ 's) first-order condition for division profit maximization, $\left(\mathrm{P}_{12}-\mathrm{C}_{1}^{\prime}\right)=0$ $\left(\left(\overline{P_{2}}-\gamma_{2}^{\prime}-P_{12}\right)=0\right)$, holds. The following tax conditions also hold when the MNC is along the supply (demand) curve: $t_{1}>t_{2}\left(t_{1}<t_{2}\right) .{ }^{12}$ The slope of the supply (demand) curve is $X_{12}^{\prime}=X_{12}^{s^{\prime}}>0\left(=X_{12}^{d^{\prime}}<0\right)$. In internal equilibrium, the MNC operates at the intersection of division 1's supply curve and division 2's demand curve, satisfying both division's first-order conditions as well as the tax condition that $t_{1}=t_{2}$. Therefore, when $t_{1}=t_{2}$, the comparative static results, which correspond to Bond's (1980) conclusion, reduce to

\footnotetext{
${ }^{11}$ See Appendix A for a derivation of the sign of CC.

${ }^{12}$ See Appendix A for a derivation of the tax conditions.
} 


$$
\partial P_{12}^{*} / \partial t_{1}=X_{12} / C C<0 \text { and } \partial P_{12}^{*} / \partial t_{2}=-X_{12} / C C>0 \text {. }
$$

When $t_{1}>t_{2}$, the MNC operates along the internal supply curve and the comparative static results reduce to

$$
\frac{\partial P_{12}^{*}}{\partial t_{1}}=\frac{X_{12}}{C C}<0 \text { and } \frac{\partial P_{12}^{*}}{\partial t_{2}}=\frac{\left(\overline{P_{2}}-\gamma_{2}^{\prime}-P_{12}\right) X_{12}^{\prime}-X_{12}}{C C}>0 .
$$

When $t_{1}<t_{2}$, the MNC operates along the internal demand curve and the comparative static results reduce to

$$
\frac{\partial P_{12}^{*}}{\partial t_{1}}=\frac{\left(P_{12}-C_{1}^{\prime}\right) X_{12}^{\prime}+X_{12}}{C C}<0 \text { and } \frac{\partial P_{12}^{*}}{\partial t_{2}}=\frac{-X_{12}}{C C}>0
$$

We conclude that whether $t_{1}=t_{2}$ or $t_{1} \neq t_{2}$, the sign of equation (14) is always negative. Similarly, the sign of equation (15) is always positive. ${ }^{13}$

The signs of the comparative static results do not depend on differences in organization structure (i.e., CDM versus DDM). Their magnitudes may differ, however. Unlike the traditional centralized MNC (i.e., the modified Horst (1971) model), which strictly predicts a boundary solution, the decentralized MNC's top management may not select the highest or lowest transfer price allowed by tax law. It may optimally select a transfer price within the arm's length boundary. An interior solution reflects the tradeoff inherent to decentralized firms, a tradeoff between the internal constraint embodied by each division's reaction function and its tax minimization objective.

Our extended model may provide limited applicability, or generality, based on the following: (i) No outside market exists for the intra-firm good, (ii) division 2 faces a perfectly

\footnotetext{
${ }^{13}$ Dawson (1999) shows that the qualitative results are unaffected by the assumption of general functional-form supply and demand curves (pp. 97-100, 108).
} 
competitive output market, and (iii) top management knows division information (i.e., division 1's supply curve and division 2's demand curve). Our results do prove useful because they apply to relevant MNC situations, however.

Assuming no market for the intra-firm good makes sense in some cases. For example, Spicer (1988) considers a situation where top management exercises control over the "make-orbuy decision". When "the internally transferred intermediate product is idiosyncratic, and involves a large investment in transaction-specific human and/or physical capital” (pp. 319-320), internal trade may meet the best interests of the firm and, if so, top management should encourage it instead of external trade. From a broader perspective, a vertical integration strategy requires that the MNC does not use the external market, if any, to source certain inputs. "Mandated internal transactions are required in implementing a strategy of vertical integration" (Eccles 1985b, p. 79). The choice of vertical integration reflects synergistic benefits of integration, including cost savings or productivity enhancements from sourcing with a related or controlled division of the MNC. Furthermore, if a competitive external market for the intermediate good does exist, then a comparable market price also exists, leaving little room for the MNC to manipulate the transfer price from an easily identifiable arm's length price. MNCs that do not face an external market, and therefore do not face an easily discernible comparable external market price, maintain more flexibility to adjust their transfer price. Thus, an outside market for the intermediate good does not exist or matter for those MNCs relevant to an analysis of international transfer pricing abuse.

Our analysis also assumes that division 2 faces a perfectly competitive final goods market. Since MNCs operate in increasingly competitive international markets, the typical MNC faces markets nearer to a competitive market structure. As such, the typical MNC exerts little 
influence over its own price.

Finally, our analysis assumes top management knows division reaction functions. Bond's (1980) DDM, which assumes centralized transfer pricing, presumes top management possesses perfect (or at least very good) information about its divisions so that it can choose the optimal transfer price (Hansen and Kimbrell 1991, p. 84). Adopting a decentralized corporate structure copes with the agency costs associated with "impacted information" (Williamson 1975) at the division level. As Hansen and Kimbrell (1991) note, top management's "limited and untimely access to local information and cognitive limitations are key reasons why firms decentralize!” (p. 84). Therefore, assuming top management knows division information, such as division supply and demand curves, appears to contradict the DDM assumption. Nonetheless, top management, although not knowledgeable of all division information, does know how divisions responded to transfer price changes in the past. And, absent a structural change in how divisions operate, historical information concerning supply and demand curves may make a good approximation of present supply and demand curves. Therefore, centralized transfer pricing does not necessarily limit the applicability of our decentralized analysis.

\section{Negotiated Transfer Pricing}

Negotiated transfer pricing, where division managements choose the transfer price as well as the quantity of intra-firm trade, reflects common practice (Vaysman 1998; Chalos and Haka 1990; Eccles 1985b; Price Waterhouse 1984; Tang, Walter, and Raymond 1979; Wu and Sharp 1979; Vancil 1978). Therefore, we relax the centralized transfer pricing assumption. "Previous research in transfer pricing had led to the conclusion that there is no transfer price that will encourage goal-congruent behavior while at the same time preserving divisional autonomy" (Hansen and Kimbrell 1991, p. 79). This section extends the negotiated transfer pricing literature to show that, 
under a tractable bargaining structure, a firm-wide optimal solution, the modified Horst (1971) CDM solution, can occur.

Hansen and Kimbrell (1991) analyze negotiated transfer pricing in a decentralized, domestic firm (i.e., with effectively equal tax rates), assuming incomplete information between top management and division managements, sufficiently complete information between division managements, and a positive-sum bargaining game. That is, both players know that a joint benefit accrues to successful cooperation, an increase in combined division profits. Since division managements' compensation depends on division profit, they maximize their respective division's profit. First, rational divisions negotiate and select the firm-wide optimal quantity of intra-firm trade (p. 89), which equals the equilibrium quantity, because that quantity maximizes combined division profit. Second, they negotiate and select a transfer price to divide the gain in combined division profit (p. 89). Since tax rates are equal, the transfer price can allocate the joint gain without adversely affecting the firm's overall profit. The negotiated transfer price facilitates division management performance evaluation and compensation, since it enters into the calculation of division profit and division management compensation depends on division profit. Hansen and Kimbrell conclude that negotiated transfer pricing-under the "existence of a joint benefit, awareness of this benefit, and rational behavior" (p. 90) on the part of division managers-leads to goal congruence and the selection of the firm-wide optimal quantity of intrafirm trade. Assuming the "existence of common interests (joint benefit) and the ability to communicate and coordinate a joint strategy to exploit this joint benefit" (p. 85) proves critical to their cooperation.

Halperin and Srinidhi (1991) extend Hansen and Kimbrell (1991) to the international case. They ask "how transfer pricing, in the presence of differential taxation, affects the resource 
allocation and profitability of a decentralized multinational enterprise (MNE) that uses the same transfer price for tax and performance evaluation purposes" (p. 141). The negotiated transfer price incorporates three roles -- calculating division profit for tax reporting purposes, calculating division profit for management compensation purposes, and providing a sharing mechanism for the joint gain in MNC profit, if any, between the divisions. The negotiated transfer price manifests the divisions' relative "negotiating abilities" (p. 141) or "bargaining strengths" (p. 146). Complete information exists as both divisions know each other's cost and revenue information (p. 141). Implicitly, Halperin and Srinidhi assume cooperation (weakly) dominates non-cooperation, where division managements know their negotiation conforms to a positivesum game. Complete knowledge of each division's reaction function would give division managements the ability, but not necessarily the incentive, to cooperate and select the optimal intra-firm quantity and transfer price. Halperin and Srinidhi conclude that, although divisions negotiate and select the firm-wide optimal quantity of intra-firm trade, the negotiated transfer pricing does not necessarily maximize firm-wide profit. In other words, it does not produce the modified Horst (1971) CDM result, because tax payments and performance evaluation depend on the transfer price. That is, “...in the absence of any transfer-pricing rule other than the requirement that the same transfer price be used for both performance evaluation and tax purposes, the MNC's total after-tax profits will not be maximized" (Halperin and Srinidhi 1991, p. 145). Since the negotiated transfer price probably reflects the parties' relative bargaining power, no guarantee exists that the chosen transfer price equals either the upper or lower arm's length boundary.

Vaysman (1998) extends Hansen and Kimbrell (1991) to include private division information and a bargaining structure that includes the possibility that top management 
intervenes to set the transfer price (i.e., centralized transfer pricing) when a negotiation impasse occurs at the end of the negotiation period. Vaysman concludes "the negotiated transfer-pricing method in this paper allows the firm to attain the upper bound on its profits" (p. 373). This upper bound on profit, however, does not equal the modified Horst (1971) CDM result. Under the assumption of private division information, a "centralized decision-making" result emerges that is "second-best to ... the first-best profits ... in the absence of private information" (p. 355; italics original). Implicitly, Vaysman finds a lower MNC profit than the modified Horst (1971) CDM outcome because both tax payments and performance evaluation depend on the same transfer price. In other words, "Divisional profits reflect transfer prices" (p. 349) and "transfer pricing affects managerial decisions" (p. 350). As Halperin and Srinidhi (1991) show, no guarantee exists that the negotiated transfer price will equal either the upper or lower arm's length boundary because the parties' relative bargaining power determines the transfer price.

Negotiated transfer pricing receives criticism because division performance evaluation depends on negotiating ability rather than division performance (Dupuch and Drake 1964), which can lead to agency costs for the firm. "The transfer pricing problem can be considered as a problem of agency" (Eccles 1985a, p. 151). When top management cannot observe division managements' behavior and effort perfectly and division managements receive their reward based on division profit, top management's task of coordination within the firm proves more complicated because its "desire to use the transfer price to minimize the MNC's global tax liabilities may encourage slack effort by its subsidiaries' managers" (Donnenfeld and Prusa 1995, p. 231). "[I]f a [transfer pricing] method is chosen to give an advantage for tax purposes, then the use of the results of subsidiary operations for performance evaluation of managers may yield unfair results, causing managerial conflict and morale problems. This potential conflict 
between the transfer pricing method chosen and a fair performance evaluation is a primary concern in the MNC" (Borkowski 1992, p. 174). According to Eccles (1985b), "managers believe they are being treated fairly when they receive rewards that they believe are commensurate with their contribution to the company" (p. 270). "Although my study showed that transfer prices sometimes affect resource allocation decisions, this was not the dominant concern for managers. Instead, they were most concerned about how transfer prices define the roles of divisions and allocate profits between trading divisions" (Eccles 1985a, p. 157). Eccles (1985b) argues further that the transfer price's effect on managerial incentives should play a principal role in the MNC's choice of a transfer pricing policy:

There are two major criteria for evaluating whether the distribution of authority and responsibility is effective for implementing strategy: corporate performance and individual fairness. Have [division] general managers been given the appropriate level of responsibility and sufficient authority over resources to carry out this responsibility in a way that contributes to corporate performance and that is perceived by them as fair? An often-voiced complaint by managers is that their responsibility exceeds their authority - that they are held responsible for outcomes that they cannot control because they do not have the authority over the resources that determine outcomes. Vancil [1978] has shown that responsibility frequently does exceed authority....The problem of fairness is a central one in managing transfer pricing, since transfer pricing policies affect both the authority and the responsibility of 
managers. If managers believe that the transfer pricing policy results in performance measures that misrepresent their contributions to the company, or that it interferes with their ability to achieve the objectives they are responsible for, then they will believe that the policy is unfair. (p. 81)

The perceived fairness of the transfer price, and the MNC's internal transfer pricing policy that underlies the transfer price, is important because it can create an agency problem that hinders the MNC's ability to achieve its desired profit goals (Eccles 1985a, 1985b). "The traditional literature, however, focuses almost exclusively on the effects of external factors such as corporate tax differences across countries, tariffs, etc. on the setting of transfer prices" (Donnenfeld and Prusa 1995, p. 231).

In sum, Halperin and Srinidhi (1991) and Vaysman (1998) assume taxable income and performance evaluation depend on the transfer price. In the domestic case in Hansen and Kimbrell (1991), the decentralized firm achieves the firm-wide optimal quantity of intra-firm trade because minimizing division tax payments is independent of the transfer price. In the international context in Halperin and Srinidhi (1991) and Vaysman (1998), the negotiated transfer price minimizes tax payments as well as divides the joint gain in combined division profit, leading to a sub-optimal negotiated transfer price. That is, no guarantee exists that the negotiated transfer price will be selected on the upper or lower arm's length boundary. In Hansen and Kimbrell (1991), Halperin and Srinidhi (1991) and Vaysman (1998), agency costs can occur because performance evaluation reflects the transfer price, which, in turn, depends on the relative bargaining power rather than relative contribution to MNC after-tax profit. Solutions to this problem include, for example, Choi and Day's (1998) conclusion that top management can 
address the tradeoff between tax avoidance and management incentives by using incentive compensation based on multiple performance measures. In our negotiated transfer pricing model, division management performance evaluation depends on division profit, but profit does not depend on the negotiated transfer price. This removes the transfer price as a source of agency costs and sub-optimality.

\section{Negotiated Transfer Pricing: A New Approach}

Our negotiated transfer pricing model builds on Hansen and Kimbrell (1991), Halperin and Srinidhi (1991), and Vaysman (1998). We borrow the following assumptions: (1) The MNC divisions face different tax rates, (2) division management compensation depends on division profit, (3) division managements possess private information about their respective division's operations and market, (4) divisions play a positive-sum game, and (5), if negotiation impasse occurs at the end of the bargaining period, top management sets the transfer price (i.e., centralized transfer pricing). By contrast, the transfer price in our model is not used as a sharing mechanism for the joint gain (or loss) in after-tax division profit that enters into the management compensation computer program. The negotiated transfer price only minimizes the MNC's global tax liability (subject to the arm's length constraint). ${ }^{14}$ Division management performancebased compensation depends on after-tax division profit. We assume private division information (between division managements, and between divisions and top management) concerning each division's respective cost and revenue functions, reaction functions, other relevant operating information and markets, which is consistent with our DDM assumption. The divisions may share this private information with each other, if faced with adequate incentives to do so. Nonetheless, we assume that, in the context of private division information, division

\footnotetext{
${ }^{14}$ In the event of a negotiation impasse, the transfer price also coordinates and allocates resources (i.e., the quantity of intra-firm trade) within the decentralized MNC.
} 
managements possess common knowledge or publicly-available information, including information publicly-available within the MNC such as the fact that their negotiations occur in a positive-sum game. Division managements exhibit bounded rationality, but exercise due diligence when making management decisions to operate their divisions competently.

When relative bargaining power determines the transfer price, it can adversely affect manager morale, effort, and productivity. This element of arbitrariness can lead to agency costs. In our negotiated transfer pricing model, taxable division profit depends on the negotiated transfer price, but the division profit used for performance evaluation does not. In a bargaining structure that separates transfer price and performance evaluation decisions, the modified Horst (1971) CDM solution reemerges. The negotiated transfer price no longer must achieve goal congruence (i.e., aligning division management's profit goals with top management's, or reducing agency costs) and now plays a more limited role of minimizing the MNC's world-wide tax liability only. Some agency costs may remain (e.g., agency costs associated with how the firm allocates the joint gain between divisions), but they are unrelated to the transfer price. The form of the allocation mechanism, which division managements may or may not view as fair, is not critical to our analysis. We will show that an unfair allocation mechanism does not undermine our modified Horst (1971) solution for negotiated transfer pricing.

Top management implements the following two-stage bargaining structure. In stage one, division managements negotiate the transfer price and quantity of intra-firm trade to maximize the expected joint gain in after-tax division profit. In stage two, division managements negotiate the split in joint gain (loss). The incentive to maximize joint after-tax division profit is rooted in the following assumptions: (1) Performance evaluation does not depend on the negotiated transfer price; (2) division managements are rational; (3) division managements hold the 
authority to negotiate the transfer price and quantity of intra-firm trade; (4) negotiations take place in a positive-sum game, where (5) this fact is publicly-available, common knowledge; (6) the length of the bargaining period is limited; and (7) negotiation impasse triggers centralized transfer pricing. Assumption 1 ensures that the negotiated transfer price does not cause agency costs. Any concern about the tradeoff between a decentralized MNC's ability to reach optimal profits (i.e., the modified CDM Horst (1971) result) while "fostering divisional autonomy" (Chalos and Haka 1990, p. 625) becomes extraneous. The above assumptions make cooperation strictly preferable. That is, cooperation dominates a negotiation impasse and a cooperative solution obtains. In the context of a decentralized MNC facing different tax rates, a negotiation impasse triggers top management to choose a non-equilibrium transfer price (i.e., $P_{12}^{\text {Cent }} \neq P_{12}^{0}$ ). $P_{12}^{\text {Cent }} \neq P_{12}^{0}$ leads autonomous division managements to select a sub-optimal, non-equilibrium quantity of intra-firm trade (i.e., $X_{12}^{\text {Cent }}<X_{12}^{0}$ ). Negotiation impasse places division managements in the passive role of selecting an intra-firm quantity supplied and demanded as a reaction to the centralized transfer price. With cooperation, division managements negotiate a transfer price, $P_{12}^{N e g}$, at either the upper or lower arm's length boundary (a boundary solution), since this maximizes the joint gain in after-tax division profit, ceteris paribus, that they will divide in stage two. They choose the highest (lowest) allowable transfer price when $t_{1}<t_{2}\left(t_{1}>t_{2}\right)$, ceteris paribus, which equals the upper (lower) arm's-length boundary. They also choose $X_{12}^{\mathrm{Neg}}=X_{12}^{0}$ because it maximizes the joint gain in after-tax division profit, ceteris paribus. Although each division management possesses private information, the existence and knowledge of the positivesum game (reinforced by centralized transfer pricing triggered by negotiation impasse) produces the incentive for rational division managements to cooperate and share relevant information, 
information that allows them to select the equilibrium intra-firm quantity of trade and the transfer price on the arm's length boundary. Notice that, unlike Hirshleifer $(1956,1964)$, an optimum result does not depend on complete information. Under incomplete information, division managements, in the pursuit of their economic self-interest, cooperate and reveal to each other their respective reaction functions, other relevant operating and market information, and share transfer pricing studies prepared by outside experts, which are publicly available within the MNC.

Hansen and Kimbrell (1991) suggest three reasons why division managements know that negotiations are positive-sum: “(1) the role of a central authority in supplying information; (2) the expectation that a responsible divisional manager will gather information about his operating environment; and, (3) open communication which will likely lead to an exchange of information that, in turn, will lead to a mutual recognition of a joint benefit (in support of this notion, well documented examples of collusion among competing firms in open markets must be considered)" (p. 96). Top management can adopt "the role of supplying information to managers" (p. 88) to encourage division managements to choose the centralized outcome. Top management's role of information assimilator does not undermine the firm's DDM structure, since "gathering and disseminating information does not constitute an infringement on the decision-making rights of divisional managers" (p. 88). Further, division managements are "reasonably informed about their division's operating environment even without information being supplied by a central authority" (p. 88). We take this view one step further. We assume incomplete information, where each party (i.e., top management, division 1, and division 2) possesses private information. Even with private information, competent, rational division managements already know that they play a positive-sum game, especially since competent 
higher-level professionals within an MNC know publicly-available, common knowledge.

In stage two, divisions divide the joint gain (loss) in division after-tax profit. Since a given bargaining outcome probably reflects each party's relative bargaining power (Chalos and Haka 1990; Chatterjee and Samuelson 1987; Abdel-Khalik and Lusk 1974; and Dupuch and Drake 1964), a generalized Nash bargaining solution allocates the joint gain between divisions. Specifically, the relative bargaining strength of division managements determines the allocation of the joint gain. This assumption is not critical to our analysis, however.

Compliance with tax law requires the decentralized MNC to choose the transfer price on, or within, the arm's length boundary, but not outside it. By selecting a negotiated transfer price on the arm's length boundary and producing an efficient quantity of intra-firm trade, top management reaches its goal of minimizing its global tax burden (i.e., tax avoidance) while not evading its tax responsibility. The MNC reports each division's before-tax (i.e., taxable) arm's length profit on its tax return in each country (or on a consolidated tax return) using the negotiated transfer price. In stage two, division managements negotiate the split of the joint gain (loss) in after-tax profit between themselves using another method, not involving the transfer price. For performance evaluation purposes, top management enters into its division management compensation program a measure of division profit that adjusts for the negotiated allocation of the joint gain (loss). ${ }^{15}$

The MNC calculates its after-tax income, for both financial statements and performance evaluations, as follows. First, the MNC hires a qualified, independent third party to perform and

\footnotetext{
${ }^{15}$ No need exists for a second set of accounting books, because the arm's length negotiated transfer price and division management expenses, adjusted for the compensation determined by the negotiated allocation of the joint gain, appear in one set of accounting books that computes (GAAP) accounting income for financial reporting purposes and taxable income for income tax purposes. Of course, taxable income may differ from accounting income on the financial statements due to the differences between (GAAP) financial accounting and tax rules, but this difference does not reflect different transfer prices. The MNC reports the same negotiated transfer price, and the income derived from that transfer price, on its tax returns as it does on its financial statements.
} 
construct a contemporaneous transfer pricing study for the relevant intra-firm trade. In the transfer pricing study, the third party calculates a reliable interquartile range (IQR) of transfer prices for the subject intra-firm transfer(s). Second, sharing information on each division's costs and revenues (and other relevant operating information) and knowing the reliable IQR in stage one of their negotiations, division managements choose the transfer price at the upper or lower arm's length boundary (i.e., $P_{12}^{N e g}=P_{12}^{U B}$ or $P_{12}^{L B}$ ) and the quantity of intra-firm trade at $X_{12}^{\text {Neg }}=X_{12}^{0}$. Third, in stage two, division managements split the joint gain (loss) in after-tax division profit, and communicate this allocation to top management. Fourth, at the end of the accounting period, the accounting department calculates each division's before-tax profit using the negotiated transfer price and quantity of intra-firm trade, which equal $\Pi_{1}^{t}$ and $\Pi_{2}^{t}$. The divisions' joint gain (loss) in after-tax division profit is as follows:

$$
\begin{aligned}
\Pi_{J G}^{t}=\Pi_{M N C}^{t}-\overline{\Pi_{M N C}^{t-1}}=\left[\left(1-\overline{t_{1}^{t}}\right) \cdot\left(\overline{\Pi_{1}^{t}}-B_{1}^{t}\right)+\left(1-\overline{t_{2}^{t}}\right) \cdot\left(\overline{\Pi_{2}^{t}}-B_{2}^{t}\right)\right] \\
-\left[\left(1-\overline{t_{1}^{t-1}}\right) \cdot\left(\overline{\Pi_{1}^{t-1}}-\overline{B_{1}^{t-1}}\right)+\left(1-\overline{t_{2}^{t-1}}\right) \cdot\left(\overline{\Pi_{2}^{t-1}}-\overline{B_{2}^{t-1}}\right)\right]
\end{aligned}
$$

Fifth, division performance evaluation profits, which depend on the gain (loss) in after-tax profits to account for any global tax savings realized, are given as follows:

$$
\Pi_{I P E}^{t}=\overline{\Pi_{I P E}^{t-1}}+\overline{\gamma_{t}} \cdot \Pi_{J G}^{t} \text { and } \Pi_{2 P E}^{t}=\overline{\Pi_{2 P E}^{t-1}}+\left(1-\overline{\gamma_{t}}\right) \cdot \Pi_{J G}^{t}
$$

The parameter $\gamma(1-\gamma)$ measures the negotiated allocation of the joint gain (loss) to division 1 (division 2) for performance evaluation. Sixth, using the MNC's management compensation software program, division performance bonuses depend on division performance evaluation profits as follows:

$$
B_{1}^{t}=f\left(\Pi_{1 P E}^{t}\right) \text { and } B_{2}^{t}=f\left(\Pi_{2 P E}^{t}\right)
$$

Seventh, division before-tax (i.e., taxable) profit, which the MNC reports on its financial 
statements and income tax returns, are as follows:

$$
\Pi_{1 \text { Fin }}^{t}=\left(\overline{\Pi_{1}^{t}}-B_{1}^{t}\right) \text { and } \Pi_{2 \text { Fin }}^{t}=\left(\overline{\Pi_{2}^{t}}-B_{2}^{t}\right)
$$

Each division management's base salary already appears in operating expenses in $\Pi_{1}^{t}$ and $\Pi_{2}^{t}$ calculated in step 4. In equation (22), we subtract division management bonuses to compute before-tax division profit for financial and tax purposes. Eighth, the MNC calculates and reports its tax liability for each division on its tax return (or consolidated MNC tax return), and calculates its after-tax profits for financial reporting. The preceding calculations utilize the five simultaneous equations in (19), (20), and (21) (i.e., five equations and five unknowns) to capture the feedback effect that management bonuses, $B_{1}^{t}$ and $B_{2}^{t}$, exert on the joint gain in MNC profit, $\Pi_{J G}^{t} \cdot{ }^{16}$

In sum, with our bargaining structure, the modified Horst (1971) CDM outcome emerges irrespective of an inequitable allocation mechanism. Even under an allocation mechanism that depends on bargaining power where the divisions wield extremely unequal bargaining powers, the relatively stronger-bargaining division management faces an incentive to offer a concession in stage two that makes the relatively weaker-bargaining division's performance evaluation profit at least as much as last period's performance evaluation profit. The bargaining structure, which includes a negotiated transfer price that does not influence performance evaluation and a centrally-determined transfer price in the event of a negotiation impasse, provides that incentive. By unlinking the transfer price decision from the division management compensation equation, even under incomplete information a decentralized MNC can achieve the higher after-tax profits equivalent to the modified Horst (1971) CDM outcome.

\footnotetext{
${ }^{16}$ The five unknown variables are $\Pi_{J G}^{t}, \Pi_{1 P E}^{t}, \Pi_{2 P E}^{t}, B_{1}^{t}$ and $B_{2}^{t}$.
} 


\section{Licensing Intangible Assets Intra-Firm}

MNC intra-firm transfers of intangible assets are extensive. Such transfers, arguably, constitute the most important aspect of MNCs' internal trade because much of the market value of modern firms is derived from the use of intangible assets. Intangibles "have become the most critical factor for competitiveness" in the global economy (Di Tommaso, Paci and Schweitzer 2004, p. 73). Nonetheless, "little research addresses transfer pricing for intangibles" (Johnson 2006, pp. 339-340). To our knowledge, only four papers directly analyze the economics of transfer pricing for international intra-firm transfers of intangible assets, Horst (1973), Halperin and Srinidhi (1996), Boos (2003), and Johnson (2006) ${ }^{17} 18$

\section{Background and Literature Review}

An intangible asset transfer can take the form of a license grant of the right to its use, or an outright sale. We focus on the license of division 1's intangible asset(s) intra-firm to division 2. Intra-firm licensing of intangibles reflects a centralized ownership strategy, where both legal and beneficial ownership lies with one company in a controlled group (as opposed to a joint, or distributed, ownership strategy, where one company holds legal ownership but both companies share beneficial ownership) (Adams and Godshaw 2002). A licensing strategy provides the greatest opportunity for an MNC to shift profits because, when several companies within a controlled group legally own separate intangibles (or separate baskets or blocks of intangibles), "exploitation within the group is by way of a myriad of cross-licenses between operating companies" (Adams and Godshaw 2002, p. 77) The number and total (dollar) value of cross-

\footnotetext{
${ }^{17}$ An earlier version, Johnson (2005), appears at http://www0.gsb.columbia.edu/rast/Bastian.pdf.

${ }^{18}$ In related work, Kopits (1976) estimates the loss in tax revenues generated by abusive transfer pricing practices with respect to intra-firm royalties and license fees by U.S. firms operating, through direct investment, in several industrialized and less developed host countries using 1968 data. Also, Grace and Berg (1990) examine cost sharing of R\&D expenses within the MNC to shift profit.
} 
licensed intangibles makes the transfer pricing analysis complex and burdensome for tax authorities to audit, thereby creating a lower probability of a tax audit and an irrefutable tax adjustment in an audit.

Lev (2001) discusses the "economic laws governing intangible assets", including their "partial excludability" and "nonrivalry" (p. 2). ${ }^{19}$ "The benefits of tangible and financial assets can be effectively secured (appropriated) by their owners. ...The well-defined property rights of physical and financial assets enable owners to effectively exclude others from enjoying the benefits of these assets" (p. 33), or to charge a price for their use. "In the case of intangible investments, however, non-owners can rarely be precluded from enjoying some of the benefits of the investments" (p. 33), which include direct benefits derived from their use and indirect benefits (i.e., spillovers or beneficial externalities) to third parties or society. By their very nature (i.e., many are knowledge-based assets), the mere possession of an intangible asset does not exclude third parties from also possessing and using it. As described by Johnson (1970), "once new knowledge has been created it has the character of a public good, in the sense that use of such knowledge by one person does not preclude use of it by another" (p. 36) because "superior knowledge developed by a firm can be understood and applied by other firms without their having to incur the costs of developing the knowledge for themselves" (p. 52). Methods exist to exclude third parties from using one's intangible asset, most notably enforceable legal protection afforded by patents and property rights. But, "patents and property rights are not always considered effective methods of protecting new knowledge. There are at least three basic limitations to their effectiveness: the ability of competitors to invent 'around a patent', the fact

\footnotetext{
${ }^{19}$ Two important characteristics define pure public goods -- "non excludable" and "nonrival" (Varian 1992, p. 414). Non excludable in consumption means non-owners can enjoy their benefits without paying for their use, or free-ride. Nonrival in consumption means their owner's use does not reduce the amount or quality of the good available for non-owners to use.
} 
that some innovations are difficult to patent, and the fact that patents disclose enough information to enable imitators to develop variants of the basic technology patented (Geroski, 1995)" (Di Tommaso, Paci and Schweitzer 2004, p. 89). Many firms adopt informal measures to protect their intellectual property and intangible assets, such as keeping them a trade secret, making it difficult for competitors to extract usable information through reverse engineering, and requiring employee confidentiality agreements. Still, such means erect imperfect barriers to free use. Expecting an unduly rapid dissemination of proprietary intangibles, firms also seek to create competitive advantages through lead time, the learning curve, and marketing strategies. These strategies foster company and brand loyalty to create barriers to the effective marketing and sale of third-party products that use their intangible assets.

Intangible assets also are nonrival in consumption. Lev (2001) states "intangible assets are, in general, nonrival; they can be deployed at the same time in multiple uses, where a given deployment does not detract from the usefulness of the asset in other deployments. Accordingly, many intangible inputs have zero or negligible opportunity costs beyond the original investment" (p. 22). Nonrival intangible assets also entail a zero or negligible marginal cost of producing each additional unit, however measured, of the intangible (Di Tommaso, Paci and Schweitzer 2004). Further, since the majority of intangibles are public goods that are nonrival (Boos 2003, p. 18), the majority of intangible assets entail zero (or negligible) marginal production costs.

Unlike a tangible product, which entails a positive marginal production cost, a nonrival intangible asset entails zero (or negligible) marginal production costs. Once division 1 incurs the fixed (or sunk) R\&D cost of creating an intangible asset, the intangible exists and the right to its use can transfer to division 2 with zero (or negligible) marginal production cost to division 1 . Johnson (2006) correctly points out, "because of the public good nature of the asset, transferring 
the asset to Division 2 does not preclude Division 1 from using the asset itself or from transferring it to other divisions" (p. 344). Once it exists, one person's (or entity's) use of the intangible asset does not reduce the quantity of the intangible asset, however measured, available for others to use. While an intangible asset's creation often requires a substantial initial R\&D investment, its dissemination, or production, typically involves zero marginal production costs: "The cost structure of many information-related intangibles ... is characterized by large (and often sunk) initial investment and marginal-to-zero production costs" (Lev 2001, p. 44) (The term "marginal" here refers to negligible variable production costs, or negligible marginal production costs). The MNC can grant additional licenses of an existing intangible asset to others without developing or producing more units of the intangible asset.

Horst (1973) considers a transfer of a tangible product that embodies division 1's intangible asset. The tangible product embodies the intangible as a product feature or a trademark or trade name, an intangible product feature. In the ordinary course of business, however, division 1 does not transfer to division 2 the right to exploit commercially the intangible asset, except, as is customary in the sale of a product, to identify the product feature, trademark, or trade name to market and sell the product. No royalty payment is appropriate under the arm's length standard, since rights to the intangible asset did not transfer to division 2 (Reilly and Schweihs 1998, p. 472). Typically, for tangible products with product differentiation created by a valuable intangible feature, the wholesale price exceeds those of non-differentiated substitute goods. The final 1993 U.S. transfer pricing regulations in $§ 1.482-3(\mathrm{f})$ "include an express statement that imbedded intangibles will not be considered a transfer of the intangible if the controlled purchaser does not acquire any rights to exploit the intangible, other than the right to resell the tangible property under normal commercial practices" (Cole 2001, Chapter 8, p. 
22). ${ }^{20}$ By contrast, this section considers the intra-firm transfer of an intangible asset in the form of division 1 granting a license to division 2 for the right to use the intangible.

Although Horst (1973) focuses on different issues, he alludes to an important aspect of intangible assets, when he refers to "the 'public good' nature of technology" (p. 81). In his analysis, both division 1 and division 2 sell an identical tangible product in their respective countries (i.e., horizontal integration). Division 1's R\&D creates an intangible asset that is embodied by a new technology in an existing tangible product, which makes the product more attractive to consumers in both countries. Horst assumes that division 1's R\&D investment leads to an identical increase in demand for the product faced by each division. This assumption, presumably, reflects identical consumer preferences (at least with respect to the new technological aspect of the final product). Horst (1973) argues that this assumption reflects "the 'public good' nature of technology within the multinational firm”' (p. 81), referring to Johnson (1970).

Halperin and Srinidhi (1996) consider transfer pricing for intra-firm transfers of intangible assets internationally. They analyze how transfer price determination under three U.S. transfer pricing methods (TPMs) ${ }^{21}$ influences an MNC's ability to achieve resource efficiency.

\footnotetext{
20 "Coordination with intangible property rules. The value of an item of tangible property may be affected by the value of intangible property, such as a trademark affixed to the tangible property (embedded intangible). Ordinarily, the transfer of tangible property with an embedded intangible will not be considered a transfer of such intangible if the controlled purchaser does not acquire any rights to exploit the intangible property other than rights relating to the resale of the tangible property under normal commercial practices.... If the transfer of tangible property conveys to the recipient a right to exploit an embedded intangible (other than in connection with the resale of that item of tangible property), it may be necessary to determine the arm's length consideration for such intangible separately from the tangible property, applying methods appropriate to determining the arm's length result for a transfer of intangible property under $\$ 1.482-4$. For example, if the transfer of a machine conveys the right to exploit a manufacturing process incorporated in the machine, then the arm's length consideration for the transfer of that right must be determined separately under $§ 1.482-4 ”(\S 1.482-3(\mathrm{f})$; italics original).

${ }^{21}$ TPMs help taxpayers to determine a reliable arm's length price or range of prices, and the arm's length profit or income based on arm's length intra-firm prices. Under $\$ 1.482 .4(\mathrm{a})$, the calculation of an arm's length royalty for intangibles may use one or more of four TPMs: The Comparable Uncontrolled Transaction method (\$1.482-4(c)),
} 
They assume CDM, however. In contrast, our analysis assumes DDM with a predetermined exogenous arm's length range. ${ }^{22}$

Boos (2003) analyzes an MNC's international transfer pricing for intra-firm licensed intangibles under the assumptions of CDM and complete information. Boos concludes the intrafirm royalty rate is indeterminate when unconstrained ${ }^{23}$ and the $\mathrm{MNC}$ chooses the highest (lowest) allowable royalty rate when $t_{1}<t_{2}\left(t_{1}>t_{2}\right)$, which is the modified Horst (1971) result under CDM. Boos acknowledges the public good nature of most intangibles and the fact that "public good intangibles ... once produced [,] ...can be transferred at no or negligible marginal costs" (p. 18). In her analysis, however, Boos assumes a positive marginal cost of producing each unit of the intangible for transfer. ${ }^{24}$ In our analysis of the decentralized MNC, we assume a zero marginal cost of producing the intangible asset for intra-firm transfer.

Finally, Johnson (2006) considers transfer pricing for intangibles under DDM, focusing on the effects of different internal transfer pricing policies on the efficiency of each division's R\&D investment decision. Johnson considers the following transfer pricing policies: (1)

the Comparable Profits method ( $\$ 1.482-5)$, the Profit Split method ( $1.482-6)$, or unspecified methods ( $\$ 1.482-$ $4(d))$. In $§ 1.482$, an intangible asset is called "intangible property".

${ }^{22}$ We implicitly assume an exogenous arm's length range that reflects the most reliable TPM as determined under the "best method rule" ( $\$ 1.482-1(\mathrm{c}))$, in full compliance with the "arm’s length standard" $(\S 1.482-1(\mathrm{~b})(1))$. U.S. tax law uses the IQR because: "In some cases, application of a pricing method will produce a single result that is the most reliable measure of an arm's length result. [However,] In other cases, application of a method may produce a number of results from which a range of reliable results may be derived" (\$1.482-1(e)). "A taxpayer will not be subject to adjustment if its results fall within such range (arm’s length range)" (\$1.482-1(e)). "The interquartile range ordinarily provides an acceptable measure of this range" $(\$ 1.482-1(\mathrm{e})(2)(\mathrm{iii})(\mathrm{B}))$. The interquartile range is calculated according to $\S 1.482-1(\mathrm{e})(2)(\mathrm{iii})(\mathrm{C})$. .

${ }^{23}$ Constraints may include DDM and/or an exogenous arm's length constraint imposed by tax authorities.

${ }^{24}$ Since a demand-influencing intangible "can be either be a new product technology or a marketing intangible" (p. 49), Boos (2003) assumes "trademark $M$ as [the] reference intangible for both [a] technology and marketing intangible" (p. 49). "The costs of producing $M$ are V(M)" (p. 49). V(M) is the variable cost of producing the intangible $\mathrm{M}$, which corresponds to the $\mathrm{V}(\mathrm{T})$ function from her analysis of a new process technology (which is a cost-influencing intangible) (p. 45). In that analysis, "The costs of producing the technology $\mathrm{T}$ are $\mathrm{V}(\mathrm{T})$ where $\delta \mathrm{V} / \delta \mathrm{T}>0, \delta^{2} \mathrm{~V} / \delta /^{2}=0 "($ p. 45$)$. 
Centralizing transfer pricing, where top management sets the royalty rate before divisions make R\&D investments; (2) negotiated transfer pricing, where divisions negotiate the royalty rate after division 1 invests in R\&D and cannot renegotiate the original license contract, and (3) negotiated transfer pricing, where divisions can renegotiate the royalty rate after division 1 invests in R\&D. ${ }^{25}$ Under negotiated transfer pricing with renegotiation, Johnson concludes renegotiation can generate efficient ex ante investment incentives for both divisions. In a discussion, Baldenius (2006) suggests Johnson's "key contribution really lies in highlighting the importance of the opportunity cost of internal transfers, i.e., the role of alternative uses for the asset" (p. 375). As Johnson notes, "transfer pricing for intangible assets is different from transfer pricing for tangible goods in important ways" (p. 341), including their "public good" nature, about which she states "once it has been developed, it can be disseminated at zero cost" (p. 344). Presumably, she means that the intangible is nonrival. On the other hand, because of "the inability of local legal systems to fully protect the asset from appropriation by other parties" (p. 344), it is nonexcludable, absent strong legal protections. ${ }^{26}$ Therefore, Johnson assumes that division 1's marginal opportunity cost of transferring the intangible asset internally, which she defines as "the price the outside firm is willing to pay" (p. 341) for the intangible, equals zero. That is, "[i]f the asset is a public good, ... there are no opportunity costs associated with its transfer" (p. 353). ${ }^{27}$

\footnotetext{
${ }^{25}$ Johnson (2006) assumes the intra-firm intangible transfer reassigns ownership, as indicated by various references to the seller and buyer (rather than to a licensor and licensee) and to the initial and final owner. A "royalty" is paid for the right to use another's intangible asset as part of a license contract, while a purchase price is paid for the sale of an intangible asset. Johnson assumes the purchase price takes the form of a royalty rate because U.S. tax law favors using a royalty rate for transfers of intangibles (p. 345, footnote 13). Presumably, she refers to §1.482-4(f)(1): "Special rules for transfers of intangible property-(1) Form of consideration. If a transferee of an intangible pays nominal or no consideration and the transferor has retained a substantial interest in the property, the arm's length consideration shall be in the form of a royalty, unless a different form is demonstrably more appropriate" (italics original).

${ }^{26}$ To protect an intangible from appropriation, an MNC can limit division 1 from licensing it to third parties.

${ }^{27}$ We argue that division 1's marginal opportunity cost may not equal zero. The next best alternative use may involve division 1 using the intangible asset itself to manufacture and sell its own final product.
} 
Facing zero marginal opportunity cost, division 1 possesses less bargaining power, expects a smaller share of the negotiation surplus, and under-invests in developing the intangible asset. ${ }^{28}$ Intra-Firm Licensing of Intangible Assets in the Synthesis Model

This section considers how division 1's (i.e., the licensor's) zero marginal production cost of transferring, under license, any quantity of the intangible asset to division 2 affects a decentralized MNC's transfer price response to a given change in relative tax rates. Specifically, how strong are the incentives it faces to choose a transfer price outside the arm's length boundary? First, to establish a baseline, we consider the general case with normally-sloped internal supply and demand curves. Second, we examine the special case where division 1's marginal production cost equals zero. For any given licensed quantity of the intangible asset, however measured, division 1's marginal cost of supplying the intangible asset is zero, which we illustrate graphically by a horizontal internal supply curve located on the quantity axis in Figure 3. We then compare the two alternative cases.

The Synthesis Model with Intra-Firm Licensing. With intra-firm goods or service trade, $P_{12}$ equals the price-per-unit of the intra-firm good or service, $X_{12}$, that division 2 uses in its production and sale of the final good, $Y_{2}$. If intra-firm trade involves a licensed intangible asset, $P_{12}$ equals the royalty-per-unit of the intra-firm intangible asset, $X_{12}$, used by division 2 in its production and sale of the final good, $Y_{2}$. Since, in practice, it is difficult to measure the actual

\footnotetext{
${ }^{28}$ Johnson (2006) calls this a "hold-up" problem. We argue, however, that a significant hold-up problem may not exist with intra-firm licensing. The typical licensor experiences a significant incentive to invest in developing the intangible asset because its investment return (i.e., royalty payment) links to the licensee's sales revenue for the final product, which, in turn, creates the incentive to develop fully the intangible asset to ensure high licensee sales revenue. The typical licensor retains the right to use the intangible asset, and/or to license it to third parties, which further promotes the licensor's incentive to develop fully the intangible asset. We assume that division 1 has fully developed the intangible asset and, therefore, a hold-up problem does not exist.
} 
quantity of the licensor's intangible asset used by the licensee, $X_{12}$, the typical royalty links to the quantity of the final good sold, $Y_{2}$. Further, to better reflect the marginal increase in market power or profitability enjoyed by the licensee through its use of the licensor's intangible asset, typically the royalty base equals the licensee's sales revenue, $\bar{P}_{2} Y_{2}$. We assume that the royalty applies to 100 percent of division 2's sales revenue, $\bar{P}_{2} Y_{2}$ (which, based on the royalty contract, accrues separately from the sales of its other products). Without the license to use division 1's intangible asset, division 2 would not generate sales receipts for the final good. ${ }^{29}$ The total royalty payment per period, $R$, equals the royalty rate, $r_{12}$, times the royalty base, $\bar{P}_{2} Y_{2}$ : $R=r_{12} \cdot\left(\overline{P_{2}} Y_{2}\right)$. The royalty-per-unit of the final good sold by division 2 is $r_{12} \overline{P_{2}}$, which also is the transfer price (i.e., $\left.P_{12} \equiv r_{12} \bar{P}_{2}\right)$. By convention, we assume that $Y_{2}=f\left(X_{12}\right)=X_{12}$. Thus, the royalty-per-unit, $r_{I 2} \overline{P_{2}}$, reverts back to the royalty-per-unit of the intangible asset used by division 2, $X_{12}$. With $P_{12} \equiv r_{12} \bar{P}_{2}$, equations (2') and (3') become the following:

$$
\begin{aligned}
& \Pi_{1}=r_{12} \overline{P_{2}} X_{12}-C_{1}\left(X_{12}\right) ; \text { and } \\
& \Pi_{2}=\overline{P_{2}} X_{12}-\gamma_{2}\left(X_{12}\right)-r_{12} \overline{P_{2}} X_{12} .
\end{aligned}
$$

Under DDM, $X_{12}=X_{12}\left(r_{12} \cdot \overline{P_{2}}\right)=X_{12}\left(r_{12} ; \overline{P_{2}}\right)=X_{12}\left(r_{12}\right)$.

The General Case. The transfer price for an intangible intra-firm transfer equals $r_{12} \bar{P}_{2}$. The

\footnotetext{
${ }^{29}$ This does not mean that division 2 may not sell a similar product. For example, if the intangible reflects a design or new product technology, the new product feature may make an existing product more useful to, and therefore in higher demand by, consumers than the existing product without the new feature. Division 2 sells the new product and pays a royalty based on that product's sales revenue, and also sells a similar product without the new feature. By contrast, if the intangible improves an existing product feature, then $\bar{P}_{2} Y_{2}$ is division 2's incremental sales revenue because it reflects sales above its sales absent the licensed intangible. Division 2 then produces good 2 with the old product feature and with the improved product feature, paying a royalty only on its sales of good 2 with the improved product feature.
} 
transfer price response to a given change in tax rates equals those in equations (14) and (15), but with $r_{12} \overline{P_{2}}$ substituted for $P_{12}$. That is,

$$
d\left(r_{12} \overline{P_{2}}\right) / d t_{1}=d P_{12}^{*} / d t_{1}=A A / C C \text { and } d\left(r_{12} \overline{P_{2}}\right) / d t_{2}=d P_{12}^{*} / d t_{2}=B B / C C \cdot \cdot^{30}
$$

Top management, in its selection of the royalty rate, maximizes after-tax profit, which means the second-order condition for profit-maximization holds (i.e., $C C<0$ ). Under DDM, $X_{12}=X_{12}\left(r_{12}\right)$. The MNC's internal demand (supply) curve for the licensed intangible asset slopes downward (upward) (see Figure 2). ${ }^{31}$ Under centralized transfer pricing, division 2 (division 1) chooses a quantity of the intangible asset to license from division 1 (license to division 2) to maximize $\Pi_{2}\left(\Pi_{1}\right)$, subject to the $r_{12}$ selected by top management. To maximize $\Pi_{M N C}$, top management responds to changes in relative national corporate profit tax rates by adjusting the royalty rate, $r_{12}$, which effectively adjusts the transfer price, $r_{12} \overline{P_{2}}$. The signs and magnitudes of the comparative static results, $d\left(r_{12} \overline{P_{2}}\right)^{*} / d t_{1}$ and $d\left(r_{12} \overline{P_{2}}\right)^{*} / d t_{2}$, equal those for tangible transfers. See equations (16), (17), and (18).

A Horizontal Licensor Supply Curve. Due to the nonrival nature of an intangible asset, division 1's marginal cost of producing additional units of the intangible asset equals zero (i.e., $C_{l}^{\prime}=0$ ) and remains zero at every quantity of the intangible asset licensed (i.e., $C_{1}^{\prime \prime}=0$ ). Figure 3 illustrates this with a horizontal internal supply curve for the intangible asset located on the quantity axis. The intangible asset's past and ongoing development costs, as well as any

\footnotetext{
${ }^{30}$ See Appendix A for the definitions of AA, BB and CC.

${ }^{31}$ See Appendix A for the derivation of the slopes.
} 
maintenance costs (such as annual patent fees), remain fixed and do not vary in relation to the quantity of the intangible asset licensed (and in relation to the royalty base, licensee sales revenue).

Since division 1's marginal cost curve is its internal supply curve, the supply and demand curves intersect at a transfer price of zero. Refer to $\left(r_{12} \bar{P}_{2}\right)^{0}$ in Figure 3. At this transfer price (and implied royalty rate, $r_{12}^{0}=0$ ), the optimal quantity of intangible asset licensed intra-firm, $\mathrm{X}_{12}^{0}$, is larger than with a positive-sloped supply curve. The tax authorities still constrain the transfer price to lie within a positive arm's length range, illustrated by the two horizontal dashed lines in Figure 3. When complying with tax law, centralized transfer pricing produces an inefficient quantity of intra-firm trade within the $X_{12}^{t_{1}<t_{2}}$-to- $X_{12}^{t_{1}>t_{2}}$ range. Under the MNC's optimal internal transfer pricing policy, negotiated transfer pricing, our bargaining structure creates sufficient incentives for division managements to agree on a transfer price at either the upper or lower arm's length boundary, and to select the optimal quantity of intra-firm trade, $X_{12}^{0}$. For intra-firm intangible licensing under our negotiated transfer price bargaining structure, the lawful MNC shifts a larger before-tax profit from one country to another for a given change in its transfer price. For example, regarding a change in transfer price from the upper to the lower arm's length boundary (i.e., a change corresponding to country 1's tax rate becoming higher than country 2's), the profit shift to division 2 is measured by area ACDF in Figure 3, while the profit shift for tangible goods trade is area $\mathrm{ABEF}^{32}$ The larger (dollar) profit shift per (dollar) transfer price adjustment for intangible asset licenses gives tax authorities in high-tax countries good reason

\footnotetext{
${ }^{32}$ By contrast, if the transfer price applies to both tax returns and performance evaluations, relative bargaining or market power within the MNC's internal market probably would lead to a negotiated transfer price within the arm's length boundaries. An internal solution for the transfer price associates with a lower quantity of intra-firm trade, as determined by division 2's demand curve at the selected internal transfer price.
} 
for concern about the potential for transfer pricing abuses. In other words, intra-firm intangible asset trade may increase the incentive for transfer price abuse as well as for tax competition between jurisdictions, important issues for tax authorities.

When an MNC perceives the arm's length range as a guideline, rather than a strict constraint, it estimates the probability of a tax audit (or a tax adjustment in an audit) along with the potential tax savings when deciding if, or by how much, to violate the arm's length range (Kant 1988). In theory, our arm's length constraint is fixed but, in practice, it may vary. The probability of audit (or tax adjustment in audit) relates inversely with the inexact nature of arm's length transfer price determination and the disinclination of tax enforcement. Given the inexact nature of the valuation and determination of the arm's length transfer price for intangibles, more room exists to push the envelope than with tangible goods trade. Practitioners know that the relative abundance of comparable uncontrolled transactions makes the determination of the arm's length range for tangible goods fairly concrete, while the relative lack of comparable uncontrolled license agreements for licensed intangibles makes the determination of the arm's length range for intangibles more debatable and controversial. The difficulty in arm's length transfer price determination for intangibles makes the estimated arm's length range for intangibles inherently less reliable and, thus, subject to greater challenge and compromise. In general, less reliable arm's length price estimates cause taxpayers to perceive a lower probability of audit (or adjustment when audited) for a given deviation from the arm's length range. For given incentives to practice transfer pricing abuse, a weaker arm's length constraint increases the likelihood of abuse, ceteris paribus.

In sum, our analysis shows that MNCs experience a greater incentive to violate the arm's length range when transferring intangible assets intra-firm under license. For a given tax rate 
change under negotiated transfer pricing, the larger quantity of intra-firm trade for intangibles raises the potential tax savings for each (dollar) transfer price deviation outside the arm's length range, strengthening the incentive and potential for transfer price abuse. ${ }^{33}$ A perceived weaker arm's length constraint releases that potential for abuse. Thus, tax authorities should audit a greater number of intangible asset transactions and invest greater resources to train tax audit specialists to identify and audit transfer pricing abuses for intangibles relative to tangibles. A binding arm's length constraint makes this result moot because a greater desire to shift profit cannot materialize. In practice, however, MNCs can, and do, set transfer prices outside the arm's length boundary, reflecting the view that the arm's length range for intangibles is a guideline rather than an unwavering, perfectly-enforced constraint.

\section{Conclusion}

This paper reviews and extends the existing literature on transfer pricing for tangible goods and intangible asset licenses, focusing on the MNC with a DDM structure. Horst (1971) provides a benchmark model for the MNC under CDM. We introduce a synthesis model to review the existing literature. In addition to our literature review, our extensions develop a strategy for the decentralized MNC to achieve the first-best outcome of Horst (1971) through negotiated transfer pricing. To do so, we separate the performance evaluation of division managers from their transfer price decision. That is, the transfer price only affects the relocation of profit between countries to minimize the MNC's tax liability, subject to transfer pricing regulations. Performance evaluation relies on a management compensation program that uses a different measure of performance than the profit distribution reported for tax purposes. Further, our synthesis model considers royalties on the licensing of intangible assets between divisions of a

\footnotetext{
${ }^{33}$ Governments also experience a greater incentive to engage in tax competition.
} 
decentralized $\mathrm{MNC}$, finding a greater incentive for MNC's to practice abusive transfer pricing for intangibles than tangibles (as well as a greater incentive for governments to engage in tax competition).

In our negotiated transfer pricing analysis, top management implements a two-step bargaining process. In step one, division managements cooperate and negotiate the transfer price and quantity of intra-firm trade to maximize (minimize) the joint gain (loss) in after-tax profit. In step two, division managements divide the joint gain (loss) in profit. With our bargaining structure, divisions face sufficient economic incentives to make firm-wide optimal decisions at the division level. They select the transfer price on either the upper or lower arm's length boundary and the equilibrium intra-firm quantity of trade to maximize (minimize) the MNC's gain (loss) in after-tax profit. The MNC uses the negotiated transfer price to calculate its profits for both financial statement and tax purposes. To evaluate the performance of each division for their bonuses, however, divisions negotiate an allocation of the joint gain (loss) in MNC after-tax profit and communicate that allocation to top management for entry into its compensation program. The separation of the transfer price choice from the calculation of performance bonuses ensures the first-best solution of Horst (1971), which we call the modified Horst solution.

One might criticize our analysis because it assumes a binding arm's length constraint. For both tangible and intangible intra-firm transfers under DDM, we conclude the MNC selects a negotiated transfer price on the upper or lower boundaries of an (implicitly) undisputed, binding arm's length range, but not outside that range. In this context, does the analysis of transfer pricing abuse appear meaningful? When applying our model in practice, we relax the binding arm's length constraint assumption.

In practice, the type of intra-firm transfer (i.e., tangible or intangible) can affect the 
nature of the arm's length range. With tangible products, the availability of comparable (or nearcomparable) uncontrolled transactions and prices, as well as the more visible and understandable link between the price of tangible products and their underlying determinants, make the estimation of the arm's length range relatively transparent. Practitioners hired by MNCs cannot easily move the arm's length constraint (using alternative TPMs, or applying a given TPM in a different way) or select a transfer price outside a given arm's length range.

With intra-firm intangible licenses, a reliable arm's length range for the royalty rate proves more difficult to estimate due to the typical lack of access to privately kept comparable (or near-comparable) license agreements, the lack of comparability (or near-comparability) of available license agreements (due to the inherently diverse nature of proprietary intangible assets), and the less visible and understandable link between the price of intangible transfers and their fundamental determinants. As a result, subjectivity plays a large part in the royalty rate determination and less agreement exists about the arm's length range, such that in practice the arm's length range tax authorities estimate provides a guideline rather than a binding constraint. As a result, MNCs are tempted to select a transfer price outside the arm's length guideline range depending on the probability of a tax audit and the probability of an adjustment in a tax audit. A lower probability enhances the temptation.

In general, practitioners are more likely to challenge the arm's length range estimated by tax authorities for intangible transfers and offer an alternative transfer pricing analysis, often resulting in a much different estimate of the arm's length range. Not only are practitioners more willing to move the arm's length range based on the less precise nature and lower reliability of estimating the arm's length range for intangibles, MNCs are more willing to take a chance on selecting a transfer price outside the guideline arm's length range. In this sense, when applying 
our theoretical results to practice, we view the arm's length constraint for intangibles as a less binding, more flexible constraint that allows motivated MNCs to manipulate their transfer prices for intangibles by a greater magnitude than for their tangibles. Since the MNC experiences a greater incentive to manipulate its transfer prices for intangibles than tangibles and the nature of transfer price determination for intangibles is less precise, it is imperative for tax authorities to devote more resources to auditing intra-firm trade of intangibles. This concern becomes all the more important as a large portion of international trade occurs through intra-firm transfers with an increasing portion involving intangible assets.

\section{References:}

Abdel-Khalik, A. Rashad, and Edward J. Lusk. 1974. Transfer Pricing-A Synthesis. The Accounting Review 49(1): 8-23.

Adams, Chris D., and Gerald M. Godshaw. 2002. Intellectual Property and Transfer Pricing. International Tax Review (Supplement: Intellectual Property) 13(4): 74-81.

Baldenius, Tim. 2006. Discussion of 'Divisional Performance Measurement and Transfer Pricing for Intangible Assets'. Review of Accounting Studies 11(2-3); 367-376.

Bartlett, Christopher A., and Sumantra Ghoshal. 1993. Beyond the M-Form: Toward a Managerial Theory of the Firm." Strategic Management Journal 14: 23-46.

Bernard, Jean-Thomas, and Robert J Weiner. 1990. Multinational Corporations, Transfer Prices, and Taxes: Evidence from the U.S. Petroleum Industry, in Razin and Slemrod, eds. Taxation in the Global Economy. Chicago: University of Chicago Press.

Bernard, Jean-Thomas, and Robert J Weiner. 1989. Multinational Corporations, Transfer Prices, and Taxes: Evidence from the U.S. Petroleum Industry. NBER Working Paper No. 3013.

Bond, Eric W. 1980. Optimal Transfer Pricing When Tax Rates Differ. Southern Economic Journal 47(1): 191-200.

Booth, E. J. R., and Oscar W. Jensen. 1977. Transfer Prices in the Global Corporation Under Internal and External Constraints. Canadian Journal of Economics 10: 434-446.

Borkowski, Susan C. 1992. Organizational and International Factors Affecting Multinational Transfer Pricing, in Most, Kenneth S., ed., Advances in International Accounting, Volume 5. A Research Annual. Greenwich, Connecticut: JAI Press, pp. 173-192. 
Boos, Monica. 2003. International Transfer Pricing: The Valuation of Intangible Assets. The Hague, The Netherlands: Kluwer Law International.

Chalos, Peter, and Susan Haka. 1990. Transfer Pricing Under Bilateral Bargaining. The Accounting Review 65(3): 624-641.

Chatterjee, Kaylan and Larry Samuelson. 1987. Bargaining with Two-Sided Incomplete Information: An Infinite Horizon Model With Alternating Offers. Review of Economic Studies LIV (1987): 175-192.

Choi, Yoon K. and Theodore E. Day. 1998. Transfer Pricing, Incentive Compensation and Tax Avoidance in a Multi-Division Firm. Review of Quantitative Finance and Accounting 11: 139-164.

Cole, Robert T (Editor and principal author). 2001. Practical Guide to U.S. Transfer Pricing. $2^{\text {nd }}$ Edition, Arlington, Virginia, USA: Tax Analysts..

Copithorne, L. W. 1971. International Corporate Transfer Prices and Government Policy. Canadian Journal of Economics IV: 324-341.

Dawson, Peter C. 1999. Transfer Price Determination in a Multinational Corporation: Decentralized Decision-Making, Agency Costs, and Strategic Interaction. Ph.D. Dissertation, The University of Connecticut.

Dean, Joel. 1955. Decentralization and Intra-Company Pricing. Harvard Business Review 33(4): 65-74.

Diewert, W. Erwin, William F. Alterman, and Lorraine Eden. 2004. Transfer Prices and Import and Export Price Indexes: Theory and Practice. June 4, 2004 version, which was presented at the SSHRC Conference on Price Index Concepts and Measurement held at the Fairmont Waterfront Hotel, Vancouver Canada, June 30-July 3, 2004.

Diewert, W. Erwin, William F. Alterman, and Lorraine Eden. 2005. Transfer Prices and Import and Export Price Indexes: Theory and Practice. March 18, 2005 version. University of British Columbia, Department of Economics, Discussion Paper 05-08.

Di Tommaso, Marco R., Daniele Paci and Stuart O. Schweitzer. 2004. Clustering of Intangibles, pp. 73-102 in Bianchi, Patrizio, and Sandrine Labory, Eds., The Economic Importance of Intangible Assets, Burlington VT, USA: Ashgate Publishing Company.

Donnenfeld, Shabtai, and Thomas J. Prusa. 1995. Monitoring and Coordination in MNCs: Implications for Transfer Pricing and Intra-Firm Trade. Journal of Economic Integration 10(2): 230-255. 
Dorgan, Byron. 2002. Dorgan Releases Study that Shows Multinational Corporations use Phony Pricing Schemes to Avoid \$53.1 Billion in U.S. Taxes, News Release, November 1, 2002, Byron Dorgan, U.S. Senator, North Dakota, 713 Hart Senate Office Building. Website: http://dorgan/senate.gov/newsroom/record.cfm?id=187978.

Dupuch, Nicholas, and David F. Drake. 1964. Accounting Implications of a Mathematical Programming Approach to the Transfer Pricing Problem. Journal of Accounting Research 2: 10-24.

Dworin, Lowell. 1990. Transfer Pricing Issues. National Tax Journal 43(3): 285-291.

Eccles, Robert G. 1985a. Transfer Price as a Problem of Agency, in Principals and Agents: The Structure of Business, Pratt, John W. and Richard Zeckhauser, eds. Boston, MA: Harvard Business School Press, pp. 151-186.

Eccles, Robert G. 1985b. The Transfer Pricing Problem: A Theory for Practice. Lexington, Massachusetts: Lexington Books.

Eden, Lorraine. 1985. The Microeconomics of Transfer Pricing. Chapter 2 in Rugman, Alan M., and Lorraine Eden, Multinationals and Transfer Pricing, New York: St. Martins Press, pp. 13-46.

Eden, Lorraine. 2003. The Internationalization Benefits of Transfer Pricing Manipulation. Bush School Working Paper \#315, The Bush School of Government and Public Service, Texas A\&M University.

Ernst \& Young. 2007. 2007-2008 Global Transfer Pricing Survey: Global Transfer Pricing Trends, Practices, and Analyses. International Tax Services department. Website: http://www.ey.com/global/content.nsf/International/20072008 Transfer_Pricing_Global_Survey (Last visited on January 17, 2008).

Geroski, Paul. 1995. Markets for Technology: Knowledge, Innovation and Appropriability, in Stoneman, P., Ed., Handbook of the Economics of Innovation and Technological Change, Oxford: Blackwell.

Grabski, Severin V. 1985. Transfer Pricing in Complex Organizations: A Review and Integration of Recent Empirical and Analytical Research." Journal of Accounting Literature 4: 3375.

Grace, Martin F. and Sanford V. Berg. 1990. Multinational Enterprises, Tax Policy and R\&D Expenses. Southern Economic Journal, 57: 125-138.

Grubert, Harry, and John Mutti. 1991. Taxes, Tariffs and Transfer Pricing in Multinational Corporate Decision-Making. Review of Economics and Statistics 73(2): 285-293. 
Guttman, George. 1999. International Panels Explore Challenges of Transfer Pricing. Tax Notes. 85: 590. (this summary document refers to the original 6-page document, Doc 199935039, which was released on October 28, 1999).

Halperin, Robert M., and Bin Srinidhi. 1991. U.S. Income Tax Transfer-Pricing Rules and Resource Allocation: The Case of Decentralized Multinational Firms. The Accounting Review 66(1): 141-157.

Halperin, Robert, and Bin Srinidhi. 1996. U.S. Income Tax Transfer Pricing Rules For Intangibles as Approximations of Arm's Length Pricing. The Accounting Review 71(1): 61-80.

Hansen, Don R., and Janet I. Kimbrell. 1991. Transfer Pricing and Efficiency: A Game Theoretic Perspective for Divisionalized Firms, in Schwartz, Bill N., ed., Advances in Accounting, vol. 9, Greenwich, Connecticut: JAI Press, pp. 79-101.

Harris, David, Randall Morck, Joel Slemrod, and Bernard Yeung. 1993. Income Shifting in U.S. Multinational Corporations, in Giovannini, Hubard, and Slemrod, eds. Studies in International Taxation. Chicago: University of Chicago Press.

Hass, Jerome E. 1968. Transfer Pricing in a Decentralized Firm. Management Science 14(6): B310 - B-331.

Hines, James R. and Eric M. Rice. 1994. Fiscal Paradise: Foreign Tax Havens and American Business. Quarterly Journal of Economics 109(1): 149-182.

Hirshleifer, Jack. 1956. On The Economics of Transfer Pricing. Journal of Business 29: 172-184.

Hirshleifer, Jack. 1964. Internal Pricing and Decentralized Decisions. Chapter 2 in Management Controls: New Directions in Basic Research, by Bonini, Charles P., Robert K. Jaedicke, and Harvey M. Wagner, Eds. New York: McGraw-Hill, pp. 27-37.

Horst, Thomas. 1971. The Theory of the Multinational Firm: Optimal Behavior under Different Tariff and Tax Rates. Journal of Political Economy 79: 1059-1072.

Horst, Thomas. 1973. The Simple Analysis of Multi-National Firm Behaviour. Chapter 5 in International Trade and Money, Connolly, Michael B., and Alexander K Swoboda, Eds. George Allen \& Unwin LTD, 1973. pp. 72-84.

Jenkins, Gordon E., and Brian D. Wright. 1975. Taxation of Income of Multinational Corporations: The Case of the U.S. Petroleum Industry. Review of Economics and Statistics 57(1): 1-11. 
Johnson, Nicole Bastian. 2005. Divisional Performance Measurement and Transfer Pricing for Intangible Assets. Working Paper. Haas School of Business, University of California, Berkeley. Website: http://www0.gsb.columbia.edu/rast/Bastian.pdf (last visited March $18,2008)$.

Johnson, Nicole Bastian. 2006. Divisional Performance Measurement and Transfer Pricing for Intangible Assets. Review of Accounting Studies 11: 339-365.

Johnson, Harry G. 1970. The Efficiency and Welfare Implications of the International Corporation, in Kindleberger, C. P., editor, The International Corporation: A Symposium. Cambridge, MA: MIT Press, pp. 35-56.

Kant, Chandler. 1988. Endogenous Transfer Pricing and The Effects of Uncertain Regulation. Journal of International Economics 24: 147-157.

Kopits, George F. 1976. Intra-Firm Royalties Crossing Frontiers and Transfer Pricing Behavior. Economic Journal 86: 791-805.

Lall, Sanjaya. 1973. Transfer-Pricing by Multinational Manufacturing Firms. Oxford Bulletin of Economics and Statistics 35(3): 173-195.

Lecraw, Donald J. 1985. Some Evidence on Transfer Pricing by Multinational Corporations. Chapter 12 in Rugman, Alan M., and Lorraine Eden, Multinationals and Transfer Pricing. New York: St. Martins Press, pp. 223-240.

Lev, Baruch. 2001. Intangibles: Management, Measurement, and Reporting. Washington, D.C.: Brookings Institution Press.

Pak, Simon J., and John S. Zdanowicz. 1994(a). An Estimate of Lost U.S. Federal Income Tax Revenues Due to Over-Invoiced Imports \& Under-Invoiced Exports. Trade Research Institute, Report 9404-01.

Pak, Simon J., and John S. Zdanowicz. 1994(b). A Statistical Analysis of the U.S. Merchandise Trade Data Base And Its Uses in Transfer Pricing Compliance and Enforcement", Tax Management Transfer Pricing Report 3(1): 50-57.

Pak, Simon J., and John S Zdanowicz. 2002. U.S. Trade with the World: An Estimate of 2001 Lost U.S. Federal Income Tax Revenues due to Over-Invoiced Imports and UnderInvoiced Exports. Executive Summary to the U.S. Senate. Website: http://dorgan.senate.gov/newsroom/extras/pak-zdan.pdf (Last visited on January 18, 2008).

Price Waterhouse. 1984. Transfer Pricing Practices of American Industry. Mimeo. Columbus Ohio. 
Reilly, Robert F., and Robert P. Schweihs. 1998. Valuing Intangible Assets. McGraw-Hill: New York.

Ronen, Joshua, and George McKinney, III. 1970. Transfer Pricing for Divisional Autonomy. Journal of Accounting Research (Spring): 99-112.

Schaub, H. James. 1978. Transfer Pricing in a Decentralized Organization. Management Accounting (April): 33-36, 42.

Schjelderup, Guttorm, and Lars Sørgard. 1995. The Multinational Firm, Transfer Pricing and The Nature of Competition. Center For Economic Studies Working Paper No. 95, Munich Germany.

Sharav, Itzhak. 1974. Transfer Pricing-Diversity of Goals and Practices. The Journal of Accountancy (April): 56-62.

Spicer, Barry H. 1988. Towards An Organizational Theory of the Transfer Pricing Process. Accounting, Organizations and Society 13(3): 303-322.

Stanley, Georgin. 2001. Transfer Pricing Takes Centre Stage. International Tax Review. 12(9): 25-31.

Tang, Roger Y. W., C. K. Walter, and Robert H. Raymond. 1979. Transfer Pricing-Japanese vs. American Style. Management Accounting (January): 12-16.

Vaitsos, Constantine V. 1974. Intercountry Income Distribution and Transnational Enterprises. Oxford: Clarendon Press.

Vancil, Richard F. 1978. Decentralization: Managerial Ambiguity by Design. Homewood, IL: Dow Jones-Irwin.

Varian, Hal R. 1992. Microeconomic Analysis. Third Edition. New York: W. W. Norton \& Company.

Vaysman, Igor. 1998. A Model of Negotiated Transfer Pricing. Journal of Accounting and Economics 25: 349-384.

Williamson, Oliver. 1975. Markets and Hierarchies: Analysis and Antitrust Implications. New York: The Free Press.

Wu, Frederick H., and Douglas Sharp. 1979. An Empirical Study of Transfer Pricing Practice. The International Journal of Accounting 14: 71-99. 


\section{Appendix A:}

Hirshleifer (1956, 1964): The first-order conditions for division 1 and 2 come from equations

(2) and (3) as follows:

$$
d \Pi_{1} / d X_{12}^{s}=P_{12}-C_{1}^{\prime}=0 \text { and } d \Pi_{2} / d X_{12}^{d}=\overline{P_{2}}-\gamma_{2}^{\prime}-P_{12}=0 .
$$

Take the total differential, set it equal to zero, and solve, giving the following results:

$$
X_{12}^{s^{\prime}}=d X_{12}^{s^{*}} / d P_{12}=1 / C_{1}^{\prime \prime}>0 \text { and } X_{12}^{d^{\prime}}=d X_{12}^{d^{*}} / d P_{12}=-1 / \gamma_{2}^{\prime \prime}<0 \text {. }
$$

With increasing marginal costs, $C_{1}^{\prime \prime}>0$ and $\gamma_{2}^{\prime \prime}>0$.

Derivation of Price Effects: The total differential of top management's first-order condition is

$$
-[A A] d t_{1}-[B B] d t_{2}+[C C] d P_{12}=0 .
$$

Solving produces the following:

$$
\frac{d P_{12}^{*}}{d t_{1}}=\frac{A A}{C C} \text { and } \frac{d P_{12}^{*}}{d t_{2}}=\frac{B B}{C C},
$$

where

$$
A A=\left[\left(P_{12}-C_{1}^{\prime}\right) X_{12}^{\prime}+X_{12}\right], \quad B B=\left[\left(\overline{P_{2}}-\gamma_{2}^{\prime}-P_{12}\right) X_{12}^{\prime}-X_{12}\right],
$$

and

$$
C C=\left(1-t_{1}\right)\left\{2 X_{12}^{\prime}-\left(X_{12}^{\prime}\right)^{2} C_{1}^{\prime \prime}+\left(P_{12}-C_{1}^{\prime}\right) X_{12}^{\prime \prime}\right\}+\left(1-t_{2}\right)\left\{-2 X_{12}^{\prime}-\left(X_{12}^{\prime}\right)^{2} \gamma_{2}^{\prime \prime}+\left(\overline{P_{2}}-\gamma_{2}^{\prime}-P_{12}\right) X_{12}^{\prime \prime}\right\} .
$$

Based on the assumption of profit-maximization, the second-order condition holds (i.e., $C C<0$ ). With linear supply and demand curves, $C C<0$, which is derived as follows. With

$$
X_{12}^{s \prime \prime}=X_{12}^{d^{\prime \prime}}=X_{12}^{\prime \prime}=0, \quad C C=\left[2 X_{12}^{\prime}\left(t_{2}-t_{1}\right)+C_{1}^{\prime \prime}\left(X_{12}^{\prime}\right)^{2}\left(t_{1}-1\right)+\gamma_{2}^{\prime \prime}\left(X_{12}^{\prime}\right)^{2}\left(t_{2}-1\right)\right] . \quad \text { With }
$$

increasing marginal costs $\left(\gamma_{2}^{\prime \prime}>0, C_{1}^{\prime \prime}>0\right)$, positive national tax rates between zero and one $\left(0<t_{1}<1,0<t_{2}<1\right)$, and $t_{1}<t_{2}\left(t_{1}>t_{2}\right)$ when the MNC operates along the $X_{12}^{d}\left(X_{12}^{s}\right)$ curve, $C C<0$ (see the next subsection for the derivation of these tax conditions). 
Derivation of Tax Conditions: When operating along division 1's supply curve, top management's first-order condition is

$$
\frac{-X_{12}}{\left(\overline{P_{2}}-\gamma_{2}^{\prime}-P_{12}\right) X_{12}^{\prime}-X_{12}}=\frac{\left(1-t_{2}\right)}{\left(1-t_{1}\right)} \text {. }
$$

Given $0<t_{1}<1 \quad$ and $0<t_{2}<1$, we know $\quad \frac{\left(1-t_{2}\right)}{\left(1-t_{1}\right)}>0$, which means $\left[\left(\overline{P_{2}}-\gamma_{2}^{\prime}-P_{12}\right) X_{12}^{\prime}-X_{12}\right]<0$. We also know $\left(\overline{P_{2}}-\gamma_{2}^{\prime}-P_{12}\right)>0$ and $X_{12}^{\prime}>0$ when the MNC operates along the supply curve, which means $\left|\left(\overline{P_{2}}-\gamma_{2}^{\prime}-P_{12}\right) X_{12}^{\prime}\right|<\left|X_{12}\right|$. Therefore, $\frac{\left(1-t_{2}\right)}{\left(1-t_{1}\right)}>1$, and $t_{1}>t_{2}$. When the MNC operates along division 2's demand curve, top management's firstorder condition is

$$
\frac{-\left[\left(P_{12}-C_{1}^{\prime}\right) X_{12}^{\prime}+X_{12}\right]}{-X_{12}}=\frac{\left(1-t_{2}\right)}{\left(1-t_{1}\right)} .
$$

We know $\frac{\left(1-t_{2}\right)}{\left(1-t_{1}\right)}>0$, which means $\left[\left(P_{12}-C_{1}^{\prime}\right) X_{12}^{\prime}+X_{12}\right]>0$. We also know $\left(P_{12}-C_{1}^{\prime}\right)>0$ and $X_{12}^{\prime}<0$ when the MNC operates along the demand curve, which means $\left|\left(P_{12}-C_{1}^{\prime}\right) X_{12}^{\prime}\right|<\left|X_{12}\right|$. Therefore, $\frac{\left(1-t_{2}\right)}{\left(1-t_{1}\right)}<1$, and $t_{1}<t_{2}$.

Intangible Assets: The terms in equation (20) equal the following:

$$
\begin{gathered}
P_{12} \equiv r_{12} \overline{P_{2}}, A A=\left[\left(r_{12} \overline{P_{2}}-C_{1}^{\prime}\right) X_{12}^{\prime}+X_{12}\right], B B=\left[\left(\overline{P_{2}}-\gamma_{2}^{\prime}-r_{12} \overline{P_{2}}\right) X_{12}^{\prime}-X_{12}\right], \text { and } \\
C C=\left[\begin{array}{r}
\left(1-t_{1}\right)\left\{2 X_{12}^{\prime}-\left(X_{12}^{\prime}\right)^{2} C_{1}^{\prime \prime}+\left(r_{12} \overline{P_{2}}-C_{1}^{\prime}\right) X_{12}^{\prime \prime}\right\} \\
+\left(1-t_{2}\right)\left\{-2 X_{12}^{\prime}-\left(X_{12}^{\prime}\right)^{2} \gamma_{2}^{\prime \prime}+\left(\overline{P_{2}}-\gamma_{2}^{\prime}-r_{12} \overline{P_{2}}\right) X_{12}^{\prime \prime}\right\}
\end{array}\right] .
\end{gathered}
$$


Slopes of Demand and Supply Curves: Division 2's first-order condition for profit maximization equals the following:

$$
\partial \Pi_{2} / \partial X_{12}=\overline{P_{2}}-\gamma_{2}^{\prime}-r_{12} \overline{P_{2}}=0 .
$$

It chooses a quantity of the intangible asset to license intra-firm at the point where its net marginal revenue from selling good $2, \overline{P_{2}}-r_{12} \overline{P_{2}}$, equals its marginal cost of producing good 2, $\gamma_{2}^{\prime}$. The total differential of the first-order condition provides the slope of division 2's demand curve as follows:

$$
X_{12}^{d^{\prime}}=d X_{12}^{d} / d\left(r_{12} \overline{P_{2}}\right)=-1 / \gamma_{2}^{\prime \prime}<0 \text {, or } d\left(r_{12} \overline{P_{2}}\right) / d X_{12}^{d}=-\gamma_{2}^{\prime \prime}<0 .
$$

Division 1's first-order condition equals the following:

$$
\partial \Pi_{1} / \partial X_{12}=r_{12} \overline{P_{2}}-C_{1}^{\prime}=0 .
$$

It chooses a quantity of the intangible asset to supply under the license where the marginal royalty revenue, $r_{12} \overline{P_{2}}$, equals the marginal cost of producing the intangible asset, $C_{1}^{\prime}$. The total differential provides the slope of division 1's supply curve generates the following:

$$
X_{12}^{s \prime}=d X_{12}^{s} / d\left(r_{12} \overline{P_{2}}\right)=1 / C_{1}^{\prime \prime}>0, \text { or } d\left(r_{12} \overline{P_{2}}\right) / d X_{12}^{s}=C_{1}^{\prime \prime}>0 .
$$


Figure 1: $\quad$ Hirshleifer $(1956,1964)^{34}$

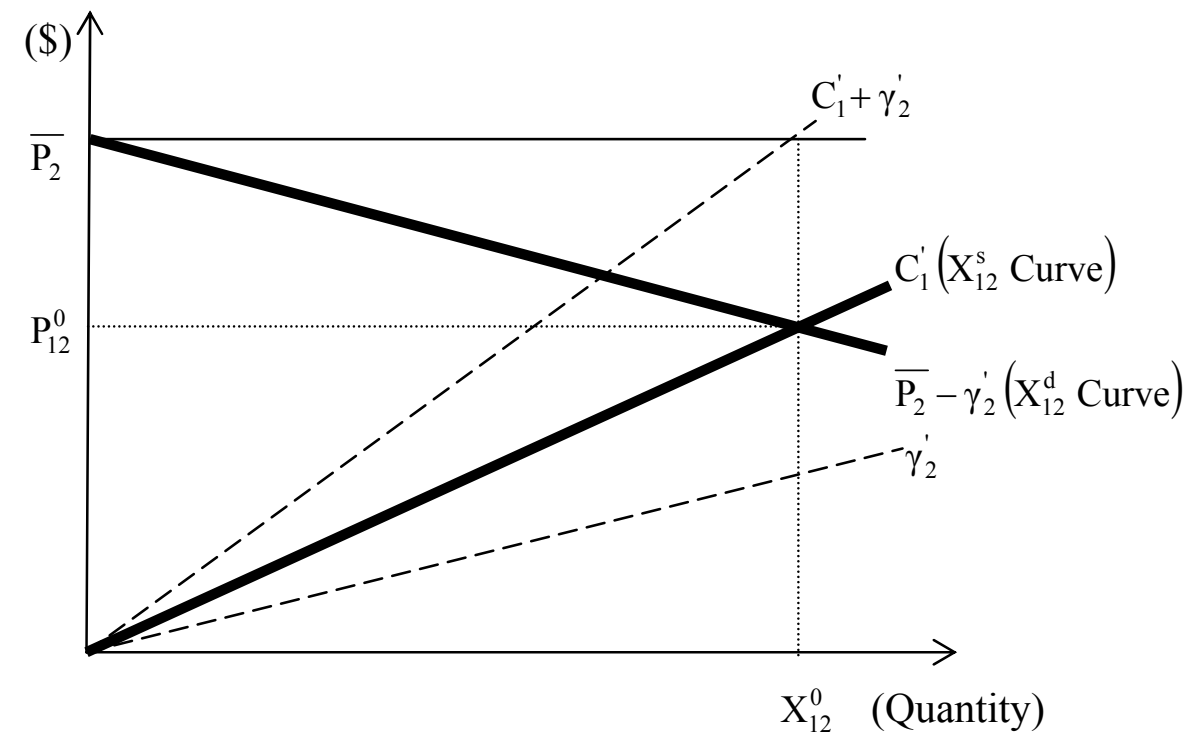

Figure 2: $\quad$ Transfer Pricing for Intangibles; General Case

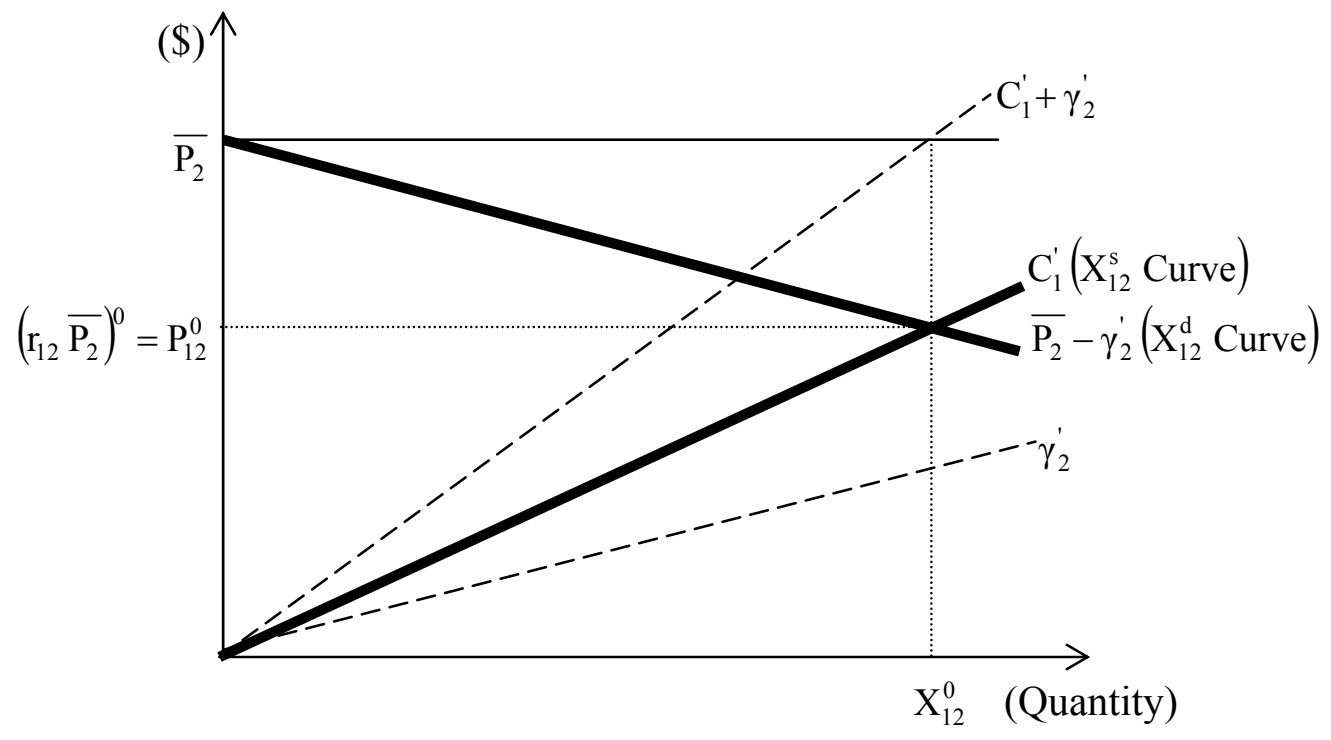

${ }^{34}$ Hirshleifer's $(1956,1964)$ original analysis assumes $C_{1}^{\prime \prime \prime}>0$ and $\gamma_{2}^{\prime \prime \prime}>0$. To simplify, we assume marginal costs are linear. 
Figure 3: $\quad$ Transfer Pricing for Intangibles: Horizontal Supply

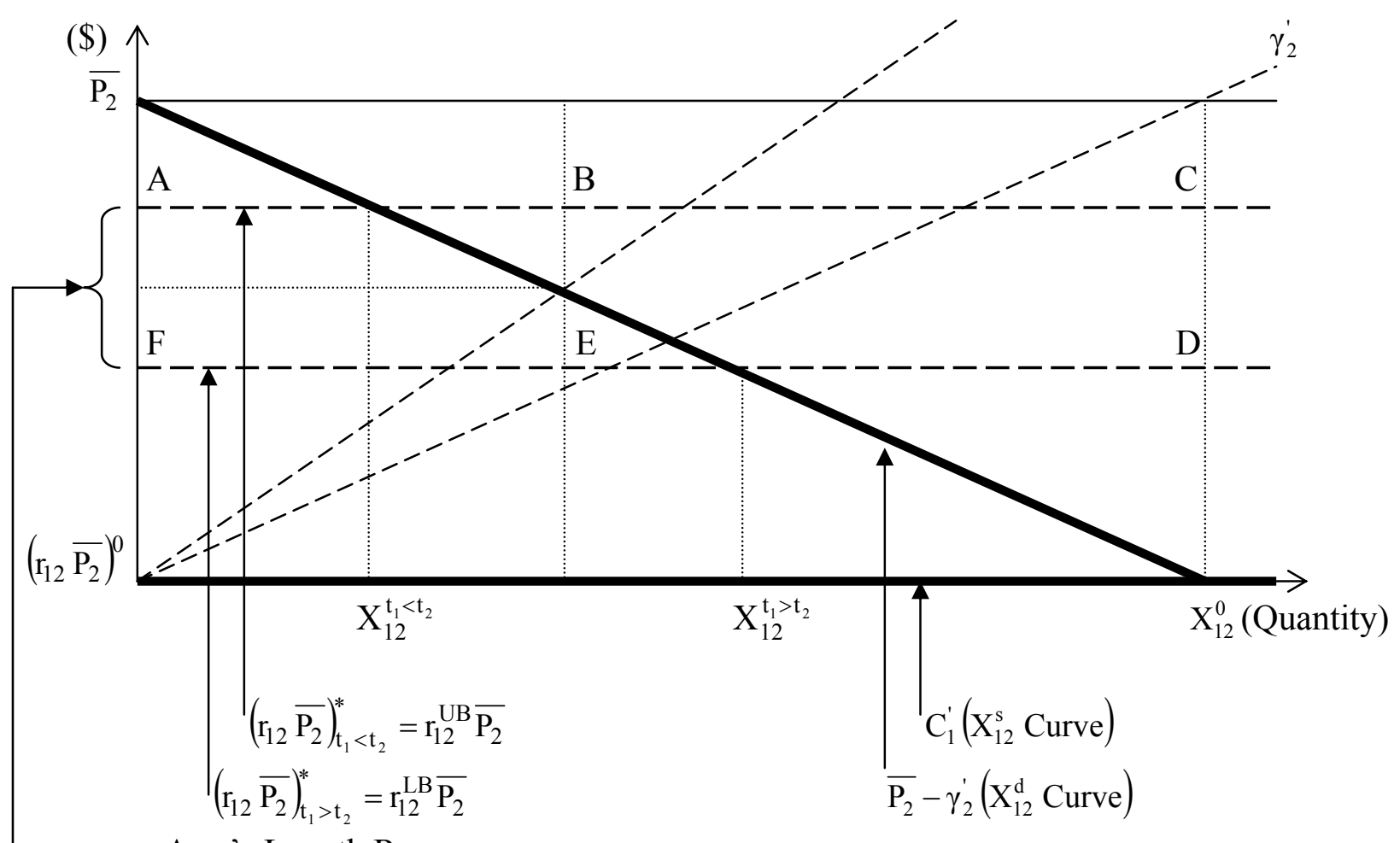

Arm's Length Range 